\title{
5-Hydroxytryptophan (5-HTP): Natural Occurrence, Analysis, Biosynthesis, Biotechnology, Physiology and Toxicology
}

\author{
Massimo E. Maffei
}

check for updates

Citation: Maffei, M.E.

5-Hydroxytryptophan (5-HTP): Natural Occurrence, Analysis, Biosynthesis, Biotechnology, Physiology and Toxicology. Int. J. Mol. Sci. 2021, 22, 181. https:/ /dx.doi.org/10.3390/ ijms22010181

Received: 4 December 2020 Accepted: 23 December 2020 Published: 26 December 2020

Publisher's Note: MDPI stays neutral with regard to jurisdictional claims in published maps and institutional affiliations.

Copyright: (c) 2020 by the author. Licensee MDPI, Basel, Switzerland. This article is an open access article distributed under the terms and conditions of the Creative Commons Attribution (CC BY) license (https: / / creativecommons.org/ licenses/by/4.0/).
Department of Life Sciences and Systems Biology, University of Turin, Via Quarello 15/a, 10135 Turin, Italy; massimo.maffei@unito.it; Tel.: +39-011-670-5967

\begin{abstract}
L-5-hydroxytryptophan (5-HTP) is both a drug and a natural component of some dietary supplements. 5-HTP is produced from tryptophan by tryptophan hydroxylase (TPH), which is present in two isoforms (TPH1 and TPH2). Decarboxylation of 5-HTP yields serotonin (5-hydroxytryp tamine, 5-HT) that is further transformed to melatonin ( $N$-acetyl-5-methoxytryptamine). 5-HTP plays a major role both in neurologic and metabolic diseases and its synthesis from tryptophan represents the limiting step in serotonin and melatonin biosynthesis. In this review, after an look at the main natural sources of 5-HTP, the chemical analysis and synthesis, biosynthesis and microbial production of 5-HTP by molecular engineering will be described. The physiological effects of 5-HTP are discussed in both animal studies and human clinical trials. The physiological role of 5-HTP in the treatment of depression, anxiety, panic, sleep disorders, obesity, myoclonus and serotonin syndrome are also discussed. 5-HTP toxicity and the occurrence of toxic impurities present in tryptophan and 5-HTP preparations are also discussed.
\end{abstract}

Keywords: 5-hydroxytryptophan; natural sources; microbial production; biosynthetic pathways; physiological effects; animal; human

\section{Introduction}

L-5-hydroxytryptophan (5-HTP) is produced from tryptophan by tryptophan hydroxylase (TPH) and its decarboxylation yields serotonin (5-hydroxytryptamine, 5-HT), a monoamine neurotransmitter involved in the modulation of mood, cognition, reward, learning, memory, sleep and numerous other physiological processes [1]. 5-HT is further transformed to melatonin ( $\mathrm{N}$-acetyl-5-methoxytryptamine), the hormone primarily released by the pineal gland that regulates the sleep-wake cycle [2,3]. Therefore, the biosynthesis of 5-HTP is important and necessary for the production of key molecules such as 5-HT and melatonin. 5-HTP also plays a major role both in neurologic and metabolic diseases and its synthesis from tryptophan represents the limiting step in 5-HT and melatonin biosynthesis [4]. The occurrence of 5-HTP is not limited to animals or humans and the molecule is produced by lower and higher plants, mushrooms and microbes (see below).

5-HTP is both a drug and a natural component of some dietary supplements and occurrence in both synthetic tryptophan and 5-HTP of toxic impurities has caused eosinophilia myalgia syndrome cases [5-8]; therefore, accurate chemical analyses and characterization have been developed. Recently, microbial engineering allowed the production of 5-HTP from alternative biosynthetic routes, opening the interesting possibility of better controlling the presence of contaminants.

This review describes the natural sources of 5-HTP, which represent the raw material from which 5-HTP may be extracted and purified for its use in drugs and dietary supplements, as well as alternative microbial synthesis that is considered a stable and sustainable way to provide a constant supply of the molecule. Chemical synthesis and chemical analysis of 5-HTP are discussed, along with the major biochemical pathways involved in 5-HTP biosynthesis and transformation, with particular reference to tryptophan 
hydroxylase. The physiological role of 5-HTP is discussed by considering both animal studies and human clinical trials. The toxicology of 5-HTP and the potential occurrence of toxic impurities are also discussed.

\section{Databases, Exclusion and Inclusion Criteria}

The strategy that was implemented to carry out this review was based on a deep search in the databases Web of Science (1985-2020) and PubMed (1940-2020) by considering, as the main entry, the term 5-hydroxytryptophan. The total number of Web of Science Core Collection papers was 1857, whereas the total number in PubMed was 5431 papers. There were 816 selected papers in the first search (see Supplementary File S1) and the exclusion criteria were the impossibility to obtain a full text and the lack of specificity with respect to the selected areas of the review. Out of the 816 papers, 195 were used for this review because of the historical, breakthrough and innovative content.

\section{Natural Sources of 5-HTP}

Plants are a rich source of 5-HTP and Griffonia simplicifolia Baill. (Caesalpinaceae) (also known as the alternate incorrect name Bandeiraea simplicifolia) seeds are the most used for the extraction and the commercial production of 5-HTP. Preparations of G. simplicifolia containing high concentrations of 5-HTP are used to treat serotonin-related disorders, including motion sickness [9] and to increase the feeling of satiety associated with a significant reduction of food intake and body weight with decreasing body mass index (BMI) $[10,11]$. The extract also shows anxiolytic-like effects [12]. The authentication of G. simplicifolia seeds is based on methods that are often laborious, time-consuming and sensitive to interference from co-occurring materials. Rapid and simple estimation procedures have been developed for the identification and quantification of 5-HTP in G. simplicifolia extracts [13,14]. Recently, the combination of chemical analysis (with the characterization of 5-HTP along with the $\beta$-carboline alkaloid derivatives) and molecular DNA fingerprinting (DNA restriction fragment length polymorphism-PCR-RFLP—analysis which has been performed on the plant internal transcribed spacer-ITS) allowed the unequivocal identification of commercial $G$. simplicifolia seeds [15].

Both 5-HTP and 5-hydroxytryptophan hydrate have been identified in the root allelochemical exudates from the aggressive weed couch grass, Elytrigia (Agropyron) repens [16], whereas quack grass (Agropyron repens L. Beauv.) accumulates throughout the plant high levels of 5-HTP as glucosides attached in $\beta$-linkages to the 5-O-indolyl moiety [17]. St. John's wort (Hypericum perforatum cv. Anthos) stem explants were found to produce significant amounts of 5-HTP when plantlets were regenerated from thidiazuron-induced tissue grown on a basal culture medium for 2 months [18], whereas 5-HTP was detected during the alcoholic fermentation of some grape cultivars [19]. Food processing may alter the 5-HTP content. The cooking (boiling, steaming, and microwaving) of the cauliflower genotypes Forata (white inflorescence), Verde di Macerata (green inflorescence), Cheddar F1 (yellow inflorescence), and Graffiti (purple coloration) was found to increase tryptophan levels and to reduce the content of 5-HTP [20].

Interestingly, other organisms are potential sources of 5-HTP. The intertidal sponge Hymeniacidon heliophila, which survives under intense sunlight, contains 5-HTP as a major constituent [21], whereas methanolic extracts of the mushrooms Boletus edulis, Suillus luteus, and Pleurotus ostreatus contain, among other indole compounds, fairly good amounts of 5-HTP [22]. The fruiting bodies of the mushroom Cantharellus cibarius (the chanterelle) and the mycelium of this species cultured in vitro contain eight indole compounds, including 5HTP [23], while the concentration of 5-HTP was higher in the stipes of five species of the fungal genus Panaeolus (P. ater, P. rickenii, P. papilionaceous, P. sphinctrinus, and P. subbalteatus) [24].

\section{Qualitative and Quantitative Analysis of 5-HTP}

The chemical analysis of 5-HTP is mainly performed by using high-performance liquid chromatography (HPLC) coupled to different detectors, including diode array 
(DAD), fluorescence (FD), and mass spectrometry (MS) detectors. The separation is usually performed by reverse phase $\mathrm{C}-18$ column chromatography [25]. The binary solvent system is $\mathrm{H}_{2} \mathrm{O}$ acidified with $0.1 \% v / v$ formic acid (solvent $\mathrm{A}$ ) and acetonitrile acidified with $0.1 \%$ $v / v$ formic acid (solvent $\mathrm{B}$ ). The chromatographic profiles are usually registered at 230 and $270 \mathrm{~nm}$. Quantitative analysis is usually performed by positive ion mode, often using a selective ion monitoring (SIM) method with different ionization interfaces, the most used being electrospray ionization (EI) [15]. This method, along with the use of other detectors, has been used to detect and quantify 5-HTP in plant extracts [2,14,15,26], rat serum [25], mice whole brain tissue [27], human plasma [28], human urine [29], and in the central nervous system [30,31].

Besides HPLC, other chromatographic techniques have been used to detect and quantify 5-HPT. Capillary electrophoresis (CE) has been used with different detectors to determine 5-HTP in samples of commercial dietary supplements [32], in human platelet-rich plasma [33], and immortalized rat raphe nuclei neurons [34]. A rapid method for the separation of 5-HTP was developed by using micellar electrokinetic chromatography with diode array detection [35]. The identification and quantification of 5-HTP was also achieved by the combination of solid-phase extraction pretreatment and gas chromatography-mass spectrometry based on a modified method of derivatization by silanization [36].

An NMR-based approach showed that 5-HTP results in characteristic chemical shift correlations suited for its identification and quantification [37], whereas the quantitative analysis of 5-HTP of carcinoid tumors was assayed using gold nanoparticles as the assisted matrix in surface-assisted laser desorption/ionization time-of-flight mass spectrometry [38]. A green fluorescence transient 5-HTP is obtained by multiphoton near infrared excitation and this technique enables the detection of 5-HTP with extremely high sensitivity. The potential application of such a method is in the imaging of biological systems and the investigation of protein dynamics [39]. Both cyclic voltammetric and UV-visible spectroscopic methods have been demonstrated to show linear responses over a wide concentration range of 5-HTP, with low limits of detection also in dietary supplements [40].

Electrochemical sensors have also attracted much attention for the detection and quantification of 5-HTP. Their high sensitivity and miniaturization are expected to overcome the shortcomings of high-cost, time-consuming, and complicated operations linked to chromatographic methods. Various types of surface-modified electrodes have been developed to determine 5-HTP such as a carbon nanosheet-modified electrode [41], $\mathrm{Ru}^{\mathrm{II}}$ terpyridinedoped composite electrode [42], gold-modified pencil graphite electrode [43], graphenechitosan molecularly imprinted film modified on the surface of a glassy carbon electrode [44], sensors based on electro-polymerization to obtain a poly-(melamine)/poly(o-aminophenol) co-polymeric film [45], nano-palladium decorated multi-walled carbon nanotubes [46], citrate-capped gold nanoparticles [47], a pyrolytic graphite electrode with the surface covered with a thin film of a nano-mixture of graphite/diamond [48], and by electrochemical microfluidic separation and sensing [49].

\section{Chemical Synthesis of 5-HTP}

The synthesis of 5-HTP by the condensation of 5-benzyloxygramine with diethyl formaminomalonate, followed by saponification, decarboxylation, and hydrogenolysis was described in 1951 [50] and 1954 [51] and was an application of gramine synthesis, developed by Snyder and Smith ten years before [52]. A few years later, another application of gramine synthesis was reported [53]. In the same year, Frangatos and Chubb [54] reported an application of the convenient tryptophan synthesis developed ten years before [55] by eliminating the difficult and tedious preparation of 5-benzyloxyindole. The $p$-benzyloxyphenylhydrazone of $\gamma, \gamma$-dicarbethoxy- $\gamma$-acetamido-butyraldehyde (Figure 1 , I) was prepared and cyclized, without isolation, to form ethyl $\beta$-(5-benzyloxyindol-3-)- $\alpha$ carbethoxy- $\alpha$-acetamidopropioilate (Figure 1, II). Saponification and partial decarboxylation of II, followed by hydrolysis of the acetamido group, gave 5-benzyloxytryptophan (Figure 1, III). 5-HTP was obtained by hydrogenolysis of III (Figure 1). However, this syn- 
thetic method suffers from the difficulty involved in the regioselective hydroxylation of tryptophan.

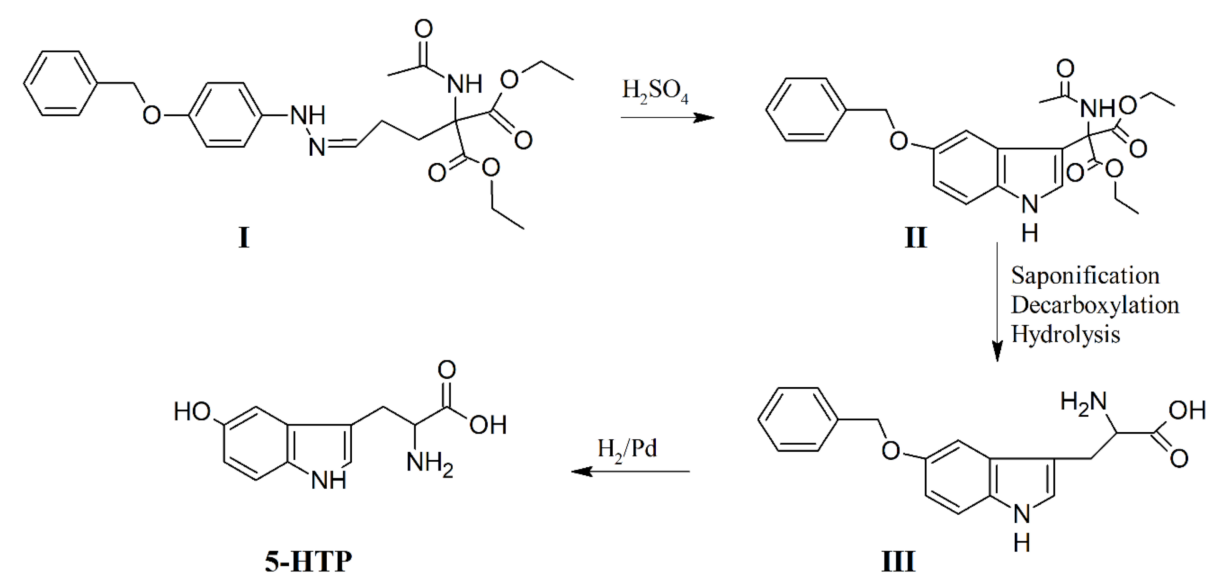

Figure 1. Chemical synthesis of 5-hydroxytryptophan (5-HTP). From [54], modified.

\section{Biosynthesis of 5-HTP and Inhibition of Tryptophan Hydroxylase (TPH)}

The biosynthesis of 5-HTP starts with the essential amino acid tryptophan, which is metabolized to 5-HTP by TPH in an initial, rate-limiting step in the biosynthesis of serotonin after the decarboxylation catalyzed by aromatic amino acid decarboxylase (AADC). TPH is a monooxygenase that belongs to the family of aromatic amino acid hydroxylases; it incorporates one atom of oxygen from molecular oxygen into the substrate and reduces the other atom to water. The two electrons required for the reduction of the second atom to water are supplied by tetrahydrobiopterin $\left(\mathrm{BH}_{4}\right)$, which acts as a substrate rather than a tightly bound cofactor, binding and dissociating each turnover [56]. The irreversible activation of $\mathrm{O}_{2}$ is the initial step in this mechanism and utilizes two electrons from $\mathrm{BH}_{4}$ to form a high-valent $\mathrm{Fe}(\mathrm{IV}) \mathrm{O}$ (ferryl) hydroxylating intermediate and 4a-hydroxypterin (4a- $\left.\mathrm{HOPH}_{3}\right)$. The $\mathrm{Fe}(\mathrm{IV}) \mathrm{O}$ intermediate subsequently reacts with the side chain of the aromatic amino acid through electrophilic aromatic substitution $[57,58]$. The binding of both the amino acid and $\mathrm{BH}_{4}$ results in a change in the coordination of the iron from six-coordinate to five-coordinate, presumably opening a coordination site for oxygen. The hydroxylating intermediate $\mathrm{Fe}(\mathrm{IV}) \mathrm{O}$ in TPH has been confirmed by rapid freeze-quench ${ }^{57} \mathrm{Fe}$ Mössbauer spectroscopy [57]. During L-tryptophan hydroxylation, $\mathrm{BH}_{4}$ is oxidized to pterin- $4 \alpha-$ carbinolamine $\left(\mathrm{BH}_{3} \mathrm{OH}\right)$ and regenerated through the function of pterin- $4 \alpha$-carbinolamine dehydratase (PCD) and dihydropteridine reductase (DHPR) $[59,60]$. Figure 2 shows the involvement of $\mathrm{BH}_{4}$ and the Fe intermediate in the reaction catalyzed by TPH.

In humans, $\mathrm{BH}_{4}$ is synthesized from guanosine triphosphate (GTP) via a three-step pathway, containing GTP cyclohydrolase I (GCHI), 6-pyruvate-tetrahydropterin synthase (PTPS), and sepiapterin reductase (SPR) [61], as shown in Figure 3.

TPH activity is assayed by a continuous spectrophotometric method that exploits the different spectral properties of tryptophan and 5-HTP [62]. The sensitivity of the essay allows the use of relatively low enzyme concentrations and can be used to determine the steady-state kinetic parameters for each of the enzyme substrates [62].

TPH is composed of three functional domains, a regulatory $N$-terminal domain, a catalytic domain, and a C-terminal oligomerization domain [63]. TPH requires ferrous iron for activity. The activity of the enzyme is affected by phosphorylation and the requirement for $\mathrm{Ca}^{2+}$ suggests a need for a calcium-dependent kinase [56]. In the rat pineal gland, norepinephrine stimulates TPH synthesis and activity and cAMP through the activation of cAMP-dependent protein kinase A (PKA), phosphorylates the transcription factor cAMP response element binding protein (CREB), which starts the enzyme synthesis, and the incorporation of at least $1 \mathrm{~mol}$ of phosphate/mol of tetramer of native TPH is required for maximal activation [64]. 


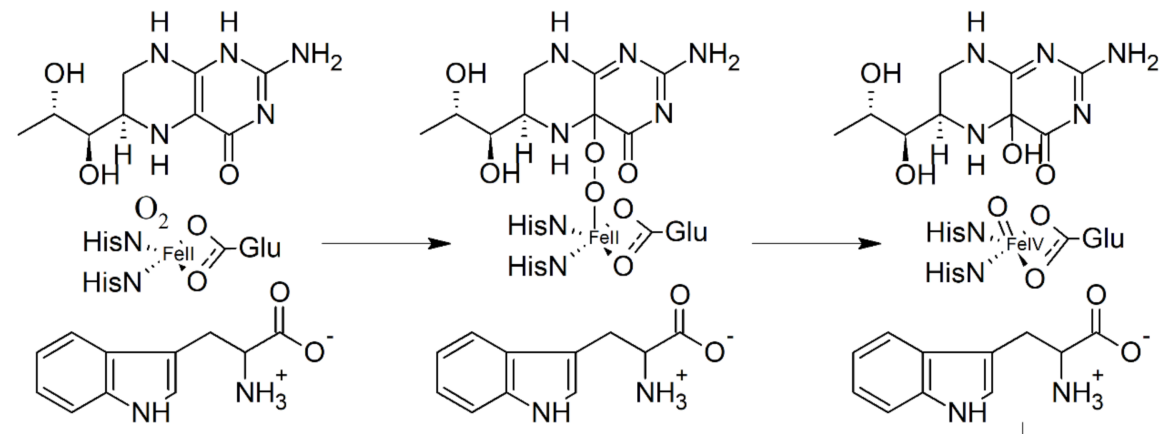<smiles>CC(O)C(O)C1CNC2=NC(N)=NC(=O)C2(O)N1</smiles><smiles>CC(O)[C@H](O)[C@H]1CNC2=NC(N)=NC(=O)C2(O)N1</smiles><smiles>[NH3+][C@@H](Cc1c[nH]c2ccc(O)cc12)C(=O)[O-]</smiles><smiles>[NH3+][C@@H](Cc1c[nH]c2c1CC(=O)C=C2)C(=O)[O-]</smiles><smiles>[CH]C1O[C@@]2(N)Oc3[nH]cc(C[C@H]([NH3+])C(=O)[O-])c3[CH+]12</smiles>

Figure 2. Hydroxylation of tryptophan by tryptophan hydroxylase (TPH). See text for explanation. From [58], modified.

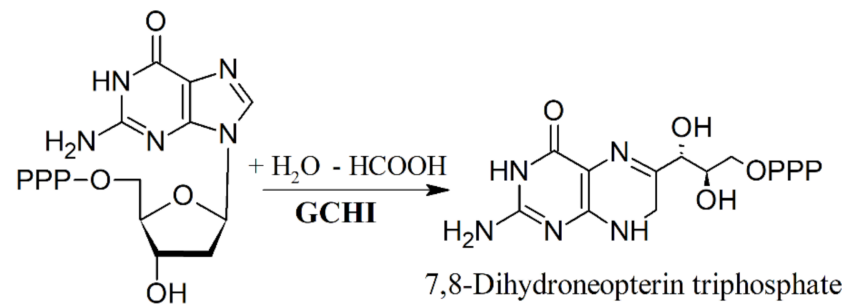

Guanosine 5'-triphosphate

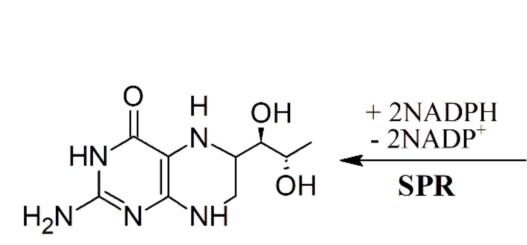

$\mathrm{BH}_{4}$ (5,6,7,8-tetrahydrobiopterin)

,8-Dihydroneopterin triphosphate

Figure 3. Biosynthesis of $\mathrm{BH}_{4}$ in mammals. Modified from [61].

In vertebrates, there are two molecular forms of TPH: TPH1 is responsible for serotonin synthesis in peripheral tissues and is mainly expressed in the enterochromaffin cells of the gut and in the pineal gland. TPH1-expressing cells of the gastrointestinal (GI) tract are responsible for blood 5-HT synthesis; 5-HTP then enters the circulation packed in dense granules of thrombocytes where it mediates its hormonal actions upon platelet release at the site of activation [65]. The second form, TPH2, is expressed in peripheral myenteric neurons in the gut and in the neurons of raphe nuclei in the brain stem but not in peripheral organs (lung, heart, kidney, or liver) [4]. Cells expressing TPH2 have rates of 5-HT synthesis which are affected by changes in tryptophan availability [66]. The presence of these two $\mathrm{TPH}$ forms justifies the duality of the 5-HT system, with two independently generated 
pools of 5-HT-one in the brain and another in the blood [65]. Antibodies that distinguish between the isoforms of TPH have been developed [67]. Figure 4 shows the central role of 5-HTP in the biochemical pathway of 5-HT.

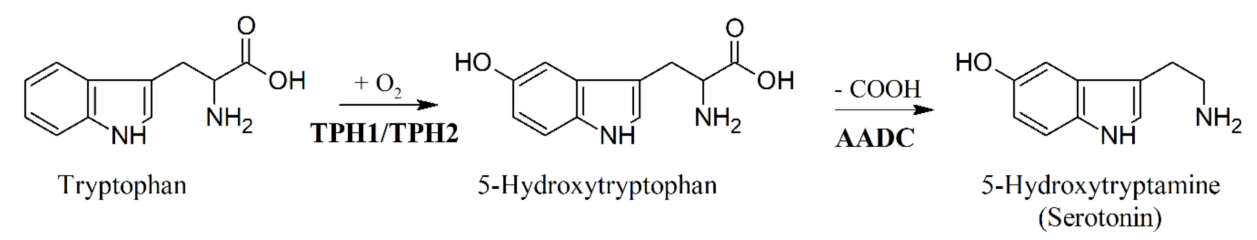

Figure 4. Biosynthetic pathway of serotonin (5-HT). Tryptophan is hydroxylated by the two forms of TPH to yield 5-HTP, which is then decarboxylated by the aromatic amino acid decarboxylase (AADC) to serotonin.

Because TPH inhibitors may provide novel treatments for various gastrointestinal disorders associated with dysregulation of the gastrointestinal serotonergic system, such as chemotherapy-induced emesis and irritable bowel syndrome, both academia and the pharmaceutical industry have worked on the search for specific TPH inhibitors. Naturally occurring unspecific inhibitors of TPH (and indoleamine metabolism) have been reported, including catecholamines, the food-derived carcinogenic heterocyclic amines 3-amino-1,4dimethyl-5H-pyrido[4,3-b]indole (Trp-P-1), and 3-amino-1-methyl-5H-pyrido[4,3-b]indole (Trp-P-2), as well as the dopamine-derived tetrahydroisoquinolines, such as salsolinol and tetrahydropapaverine [68-70]. While the inhibition of TPH by salsolinols was found to be non-competitive with the substrate L-tryptophan [68], TPH was un-competitively inhibited by tetrahydropapaverine with the substrate L-tryptophan, and non-competitively inhibited with the cofactor DL-6-methyl-5,6,7,8-tetrahydropteridin in P-815 cells [69]. In the same cell system, the inhibition of TPH by Trp-P-2 was found to be competitive with the substrate L-tryptophan and non-competitive with the cofactor DL-6-methyl5,6,7,8-tetrahydropteridin [70]. $p$-Ethynylphenylalanine ( $p$-EPA) is a more potent TPH inhibitor; $p$-EPA injection induced a significant and gradual decrease in extracellular 5 -HTP in the rat hippocampus, striatum, and frontal cortex. Moreover, $p$-EPA could also irreversibly interfere with the synthesis of TPH [71]. Selective inhibitors of TPH, such as LP-533401 [(2S)-2-amino-3-(4-(2-amino-6-(2,2,2-trifluoro-1-(3'-fluorobiphenyl-4yl)ethoxy)pyrimidin-4-yl)phenyl)propanoic acid] and LP-615819 [(2S)-ethyl 2-amino-3-(4(2-amino-6-(2,2,2-trifluoro-1-(3'-fluorobiphenyl-4-yl)ethoxy)pyrimidin-4-yl)phenyl)propan oic acid], were found to competitively bind to the tryptophan pocket of both TPH isoforms and to improve metabolic parameters, thus providing novel treatments for various gastrointestinal disorders associated with dysregulation of the gastrointestinal serotonergic system [72]. The kinetic analysis with these inhibitors showed that they are all competitive versus L-tryptophan but predominantly uncompetitive versus pterin [73]. Two other inhibitors of TPH are telotristat ethyl (the free base form of a hippurate salt called telotristat etiprate) and its active metabolite telotristat. In vitro, the inhibitory potency of telotristat was found to be 29-fold higher than that of its prodrug, with inhibition of TPH resulting in a reduced production of peripheral 5-HT [74].

A new series of acyl guanidines displaying potent TPH1 inhibition have been reported [75]; these molecules have been chemically and pharmacokinetically optimized and successfully tested in vivo [76]. 1-O-Galloylpedunculagin was screened as a drug-like compound from the traditional Chinese medicine (TCM) database for inhibitor activity on TPH. The molecule specifically inhibited TPH1 but was ineffective on TPH2, and the inhibitory action displayed characteristics of competitive inhibition [77]. The effects of nifedipine, an L-type calcium channel blocker, in noradrenergic-stimulated cultured rat pineal glands, showed that TPH activity was the main step inhibited by the molecule, demonstrating that the calcium influx through L-type high-voltage-activated calcium channels is essential for the full activation of the enzyme [78]. Figure 5 shows the chemical formulae of the TPH inhibitors cited above. 


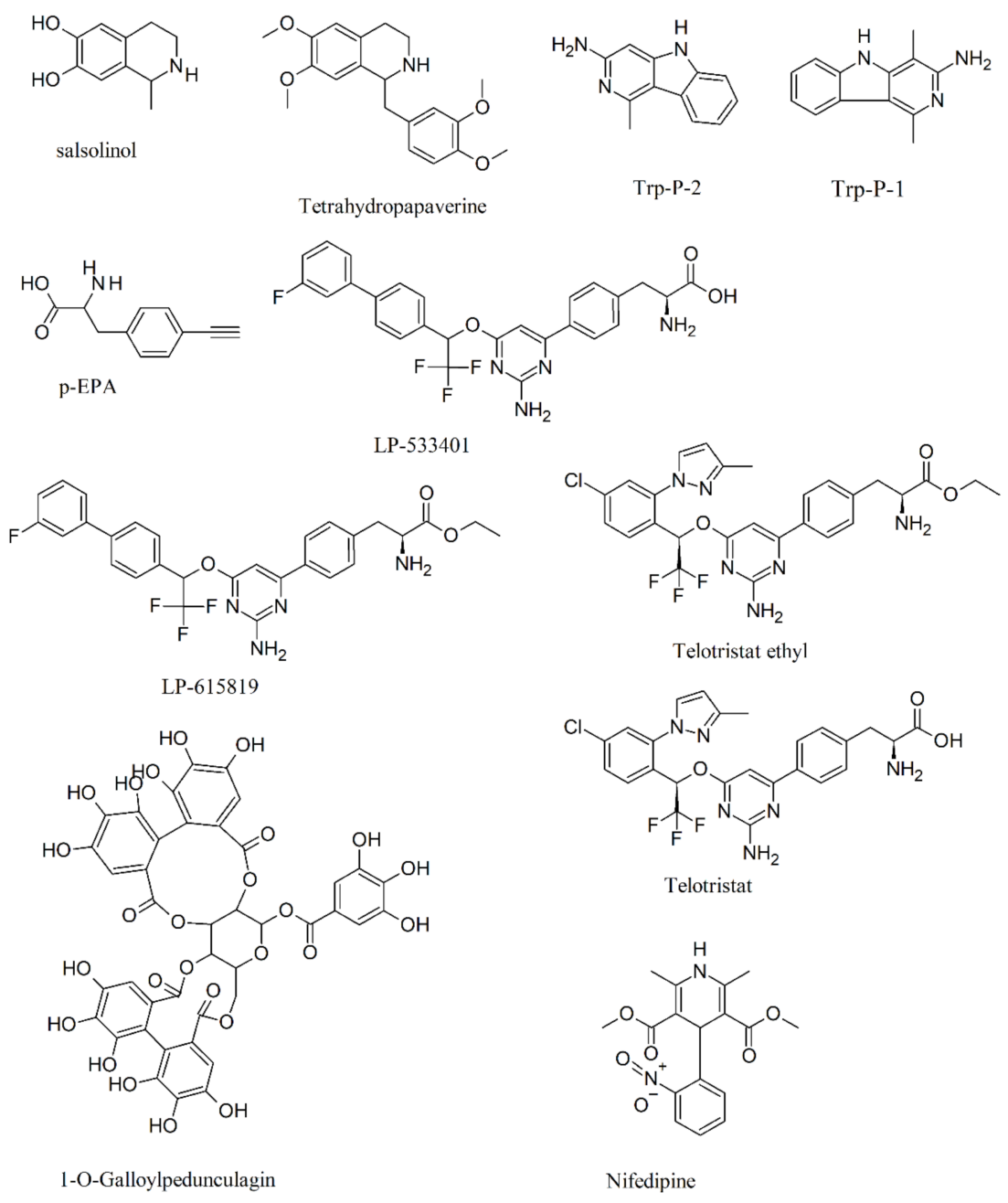

Figure 5. Structure formulae of some TPH inhibitors.

\section{Metabolic Engineering and Heterologous Production of 5-HTP}

As discussed above, extraction from the seeds of the African plant Griffonia simplicifolia is the typical approach for 5-HTP commercial production, because chemical synthesis is not economically feasible on a large scale. However, the material supply is seasonally and regionally dependent, which limits the output of 5-HTP. A promising alternative is the metabolic engineering of microorganisms. Among the many advantages, microorganisms grow quickly and their genetic engineering has been demonstrated to be a productive way to obtain important chemicals, such as aromatic compounds [79], fatty acids [80], carotenoids [81], flavors and fragrances [82], and many other natural products [83].

Although the microbial synthesis of 5-HTP has been achieved in different microorganisms, with particular reference to Escherichia coli, the first evidence of a microbial hydroxylation of tryptophan was found in Chromobacterium violaceum, about 70 years ago [84]. The function of tryptophan hydroxylation in this organism was considered important to provide the precursor for the characteristic blue pigment produced by this species, violacein, that is synthesized by a series of tryptophan metabolisms. Further characterization showed that the TPH from C. violaceum has, at least superficially, the characteristics of the TPH found in various mammalian tissues [85]. L-phenylalanine 4-hydroxylase from C. violaceum could convert L-tryptophan to 5-HTP and L-phenylalanine to L-tyrosine; however, the activity for L-tryptophan is extremely low compared to Lphenylalanine activity levels. The L-tryptophan hydroxylation activity of $C$. violaceum L-phenylalanine 4-hydroxylase (CviPAH) was enhanced using information on its crystal structures by introducing a saturation mutagenesis towards L101 and W180 in C. vio- 
laceum phenylalanine 4-hydroxylase (PAH). Mutant libraries from the L101 and W180 produced several positive mutants, with L101Y and W180F showing the highest TPH activity, whereas the double mutant (L101Y-W180F) displayed higher TPH activity when compared with the wild type and the individual W180F and L101Y mutants [86]. Interestingly, pterin is still required as a cofactor for enzyme activity by the CviPAH-L101Y-W180F triple mutant, which is similar to the requirements of other types of aromatic amino acid hydroxylases [86]. A novel cofactor regeneration process to achieve enhanced synthesis of 5-HTP by using CviPAH was obtained by screening and investigating several key enzymes, including dihydropteridine reductase from E. coli, glucose dehydrogenase from Bacillus subtilis, and pterin- $4 \alpha$-carbinolamine dehydratase from Pseudomonas syringae. Genes encoding these three enzymes were overexpressed in an E. coli tryptophanase-deficient host, resulting in the synthesis of ten-fold $(0.74 \mathrm{mM}) 5-\mathrm{HTP}$ in the presence of $0.1 \mathrm{mM}$ pterin with respect to the absence of the regeneration of pterin [59].

The engineering of E. coli successfully improved the production of 5-HTP through bioprospecting and protein engineering approaches. An important achievement was the discovery that bacterial PAHs may utilize tetrahydromonapterin $\left(\mathrm{MH}_{4}\right.$, Figure 6) instead of $\mathrm{BH}_{4}$ as the native pterin coenzyme; this resulted in a great advantage because $\mathrm{BH}_{4}$ does not naturally occur in most bacteria [87].<smiles>Nc1nc2c(c(=O)[nH]1)NC([C@H](O)CO)CN2</smiles>

Tetrahydromonapterin

Figure 6. Chemical formula of tetrahydromonapterin.

Based on the potential ability of PAH to hydroxylate tryptophan, the development of PAH mutants highly active in converting tryptophan to 5-HTP allowed the establishment of an efficient 5-HTP production platform via further metabolic engineering efforts [88]. Whole-cell bioconversion allowed the high-level production of 5-HTP $(1.1-1.2 \mathrm{~g} / \mathrm{L})$ from tryptophan in shake flasks, also allowing de novo 5-HTP biosynthesis from glucose [88] (Figure 7).

In a similar strategy, the tryptophan pathway was extended by using an engineered PAH from Cupriavidus taiwanensis (CtAAAH) and the production of 5-HTP was achieved by an endogenous cofactor with an artificial regeneration system [89].

In the search of a direct alternative precursor for the biosynthesis of 5-HTP, a novel salicylate 5-hydroxylase was used to convert the non-natural substrate anthranilate to 5-hydroxyanthranilate (5-HI) produced from glucose. To assess whether 5-HI may function as a precursor of 5-HTP, a medium copy number pCStrpDCBA plasmid was constructed in the E. coli strain BW2. Knockouts of tnaA (that prevents the products tryptophan and 5-HTP from degrading) and trpE (that blocks the native synthesis of anthranilic acid) harboring pCS-trpDCBA were used for the in vivo assay. $\operatorname{trpDCBA}$ was also cloned into a low copy number plasmid, yielding pSA-trpDCBA. The in vivo assay of the strain BW2 harboring pSA-trpDCBA accumulated the intermediate 5-hydroxyindole in the cultures, indicating that the reaction catalyzed by $\operatorname{TrpB}$ was a rate-limiting step. The de novo production of 5-HTP was then established by combining the full pathway and by adopting a two-stage strategy (see Figure 8) [90]. 


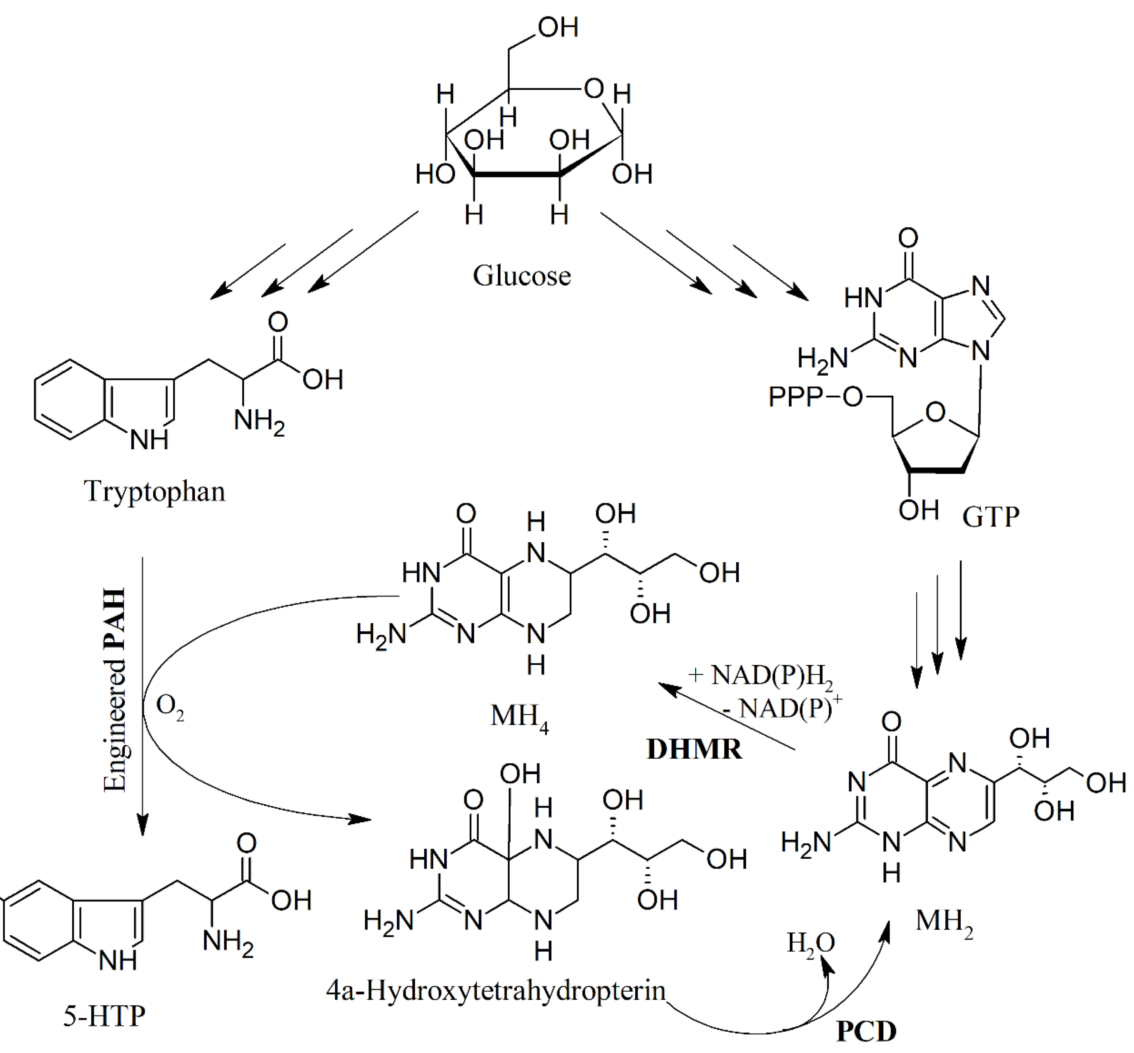

Figure 7. Production of 5-HTP from tryptophan in E. coli by engineered PAH and the utilization of tetrahydromonapterin $\left(\mathrm{MH}_{4}\right)$ instead of $\mathrm{BH}_{4}$. DHMR, dihydromonapterin reductase; $\mathrm{PAH}$, phenylalanine 4-hydroxylase; $\mathrm{PCD}$, pterin- $4 \alpha$-carbinolamine dehydratase; $\mathrm{MH}_{2}$, dihydromonapterin. Modified from [88].

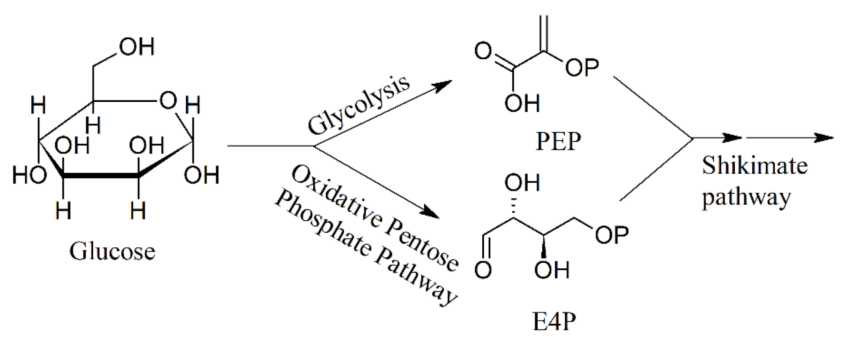<smiles>C=C(O)C(=O)OC1C=C(C(=O)O)C=CC1O</smiles>

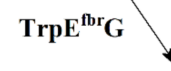

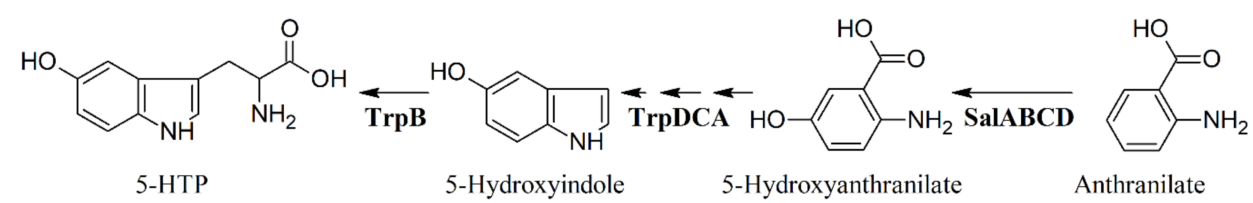

Figure 8. Production of 5-HTP from glucose in engineered E. coli by using a novel salicylate 5hydroxylase. PEP, phosphoenol pyruvate; E4P, erythrose-4-phosphate; $\operatorname{Trp} \mathrm{E}^{\mathrm{fbr}} \mathrm{G}$, anthranilate synthase (from a feedback resistance mutant); SalABCD, salicylate 5-hydroxylase; TrpDCA and TrpB, E. coli native tryptophan biosynthetic enzymes. Adapted from [90].

By engineering E. coli with heterologous TPH by using a truncated form of human TrpH2 with an E2K mutation for improved protein abundance, 5-HTP conversion from tryptophan was improved by protein engineering TPH [91]. Recently, in order to increase 5-HTP yield and stability of TPH, the tryptophan biosynthetic pathway was integrated into 
the E. coli genome. A $24.8 \%$ improvement compared to the original strain was obtained by manipulating the replication origin of the hydroxylation plasmid and by substitution of the promoter of aroH $H^{f b r}$ gene encoding 3-deoxy-7-phosphoheptulonate synthase (that catalyzes the first step of tryptophan biosynthesis). The resulted recombinant strain TRPmut/pSCHTP-LMT was able to produce $1.61 \mathrm{~g} / \mathrm{L}$ 5-HTP in shake flasks, compared to $0.160 \mathrm{~g} / \mathrm{L}$ of previous metabolic engineering productions [92].

A successful production of 5-HTP in microbial systems has been obtained in the yeast Saccharomyces cerevisiae BY4741 strain via LiAc-mediated yeast transformation. The strategy was based on the heterologous expression of either a prokaryotic PAH or eukaryotic tryptophan 3/5-hydroxylase, together with enhanced synthesis of the two cofactors $\mathrm{MH}_{4}$ or $\mathrm{BH}_{4}$ [93]. Interestingly, a native S. cerevisiae gene, DFR1, which encodes dihydrofolate reductase to catalyze tetrahydrofolate, played a pivotal role in 5-HTP synthesis by regenerating $\mathrm{MH}_{4}$ [93]. Figure 9 summarizes the heterologous 5-HTP production.

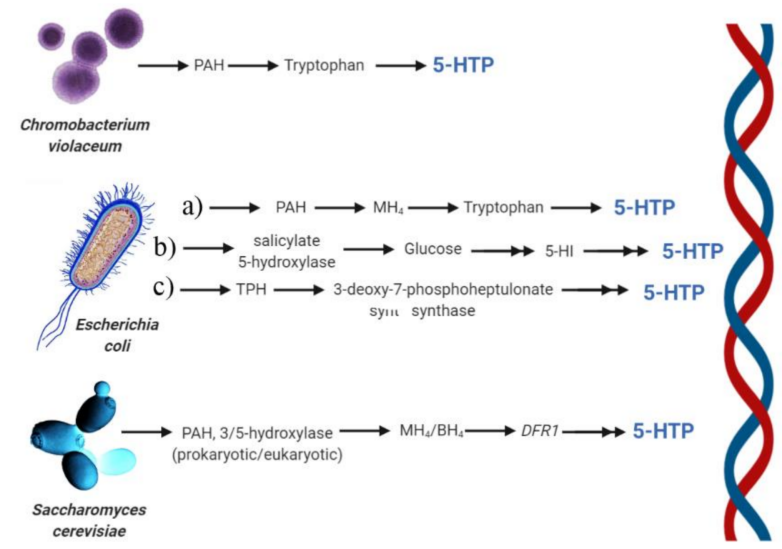

Figure 9. Summary of heterologous production of 5-HTP. Chromobacterium violaceum, with the first use of PAH for tryptophan hydroxylation to 5-HTP. Escherichia coli, with a) utilization of $\mathrm{MH}_{4}$ instead of $\mathrm{BH}_{4}$ as the native pterin coenzyme for 5-HTP synthesis, $\mathrm{b}$ ) the biosynthesis of 5-HTP with the use of a novel salicylate 5-hydroxylase that uses glucose as the substrate for the production of the non-natural substrate anthranilate to 5-hydroxyanthranilate (5-HI), c) substitution of the promoter of aroHfbr gene encoding 3-deoxy-7-phosphoheptulonate synthase to feed the biosynthetic pathway of tryptophan production. The use of yeasts with the heterologous expression of either a prokaryotic PAH or eukaryotic tryptophan 3/5-hydroxylase, together with enhanced synthesis of the two cofactors $\mathrm{MH}_{4}$ or $\mathrm{BH}_{4}$; the native Saccharomyces cerevisiae gene, DFR1, which encodes dihydrofolate reductase to catalyze tetrahydrofolate, plays a pivotal role in 5-HTP synthesis by regenerating $\mathrm{MH}_{4}$. Created with BioRender.com.

\section{Physiological Effects of 5-HTP}

\subsection{Animal Studies}

Early experiments with 5-HTP in the 1950s have shown that this molecule is also capable of inhibiting gastric hydrochloric acid secretion [94] and that when administered to animals it increased peristaltic activity [95] and was rapidly taken up by most tissues [96], producing in dogs, cats, rabbits, rats, and mice somatic, autonomic, and behavioral effects which grossly resembled those of lysergic acid diethylamide [97].

Most of the animal experimentation on the effects of 5-HTP has been conducted on mice and rats.

In mice, injection of 5-HTP produces a characteristic head twitch due to a central action of 5-HT formed by decarboxylation of 5-HTP [98] and provokes characteristic behaviors, such as tremors, that become more frequent when doses are increased [99]. The accumulation of 5-HT in the mouse liver but not in the brain is causally related to the hypoglycemia induced by 5-HTP $[100,101]$. 5-HTP also suppresses inflammation and arthritis through decreasing the production of pro-inflammatory mediators [102] and the antihistaminic drugs chloropyramine and, more strongly, chlorpheniramine potentiates the action of 
5-HTP by inhibiting serotonin uptake [103]. Interestingly, dietary phenylalanine and 5-HTP were found to be mutually antagonistic in modulating mice audiogenic seizure susceptibility [104].

In rats, at least some of the behavioral effects of 5-HTP are due to increased levels or turnover of 5-HTP in peripheral serotonergic neuronal systems [105] and 5-HTP neurotoxicity caused by brain-blood barrier breakdown, edema formation, and NO production was found to be instrumental in causing adverse mental and behavioral abnormalities [106]. For instance, the wet dog shake behavior induced by 5-HTP was dose dependent and was mediated by the activation of 5-HT2 receptors [107], whereas in iproniazid-pretreated rats, a special form of stereotyped movements of the head and forelegs and a gnawing behavior were observed after intraperitoneal administration of 5-HTP [108]. 5-HTP produced a 6-11-fold increase in rat plasma prolactin [109,110]. Moreover, endogenous opioids also increase the serum level of prolactin induced by 5-HTP; therefore, different serotonergic neurotransmitter circuits might be capable of modulating the release of corticosterone and prolactin [111]. 5-HTP was also able to induce depression in rats working on an operant schedule for milk reinforcement, and this effect was mediated by serotonergic mechanisms involving 5-HT2 receptors [112]. Moreover, administration of 5-HTP prompted a synergistic increase in the synthesis and release of 5-HT by combining 5-HT uptake inhibition with the blockade of 5-HT1A autoreceptors [113]. Another interesting effect of 5-HTP in rats is the reduction in meal size and a slowing of eating, exerting an effect on the patterns of feeding [114].

Myoclonic twitches, jerks, or seizures are usually caused by brief lapses of contraction (negative myoclonus) or sudden muscle contractions (positive myoclonus). In guinea pigs, when 5-HTP was given $6 \mathrm{~h}$ after $0.5 \mathrm{mg}$ progesterone in estradiol benzoate-primed males, myoclonus was enhanced, whereas progesterone reversed the facilitative effect of estradiol benzoate on 5-HTP-induced myoclonus in females [115]. It was also found that 5-HTP-induced myoclonus was influenced by the $5-\mathrm{HT} 1 / 2$ receptor systems and that the absence of a significant change with a receptor antagonist implied that myoclonus was not related to diffuse activation of central serotonergic mechanisms [116]. In the guinea pig colon, 5-HTP facilitates the luminal 5-HT release from enterochromaffin cells, with no involvement of neuronal mechanisms and a non-neuronal cholinergic system [117].

In the terrestrial snail Helix lucorum, injection of 5-HTP alone did not restore the protein kinase M zeta (ZIP)- or the protein synthesis blocker anisomycin-impaired context memory, while the combination of 5-HTP and the reactivation of memory effectively reinstated the context memory [118].

In rabbits, 5-HTP injected intracisternally at a dose of 1.5-3 mg produced a fall in temperature often followed by a rise beyond the pre-injection level, and the anterior hypothalamus was supposed to be the site where 5-HTP acted [119]. To antagonize rabbit 5-HTP-induced hyperthermia, 5-HT receptor blockade is required and antagonism of $p$ methoxyamphetamine-induced hyperthermia is primarily a result of influence on the 5-HT system [120].

In cats, intrahypothalamic injection of 5-HTP allowed its detection in many fibers surrounding the injection site [121], whereas lysergic acid diethylamide was found to mimic the actions of 5-HTP by facilitating the stretch reflex and exciting extensor gamma motoneurons in the animal spine [122].

In dogs, the administration of 5-HTP increased both blood and tissue serotonin with a maximum effect evident in about one hour [123] and increased the propulsive activity, the contractile force, and the motility index [124]. In monoamine oxidase (MAO)-inhibited dogs, 5-HTP caused hypotension with variable effects on heart rate and the cerebral decarboxylation and formation of 5-HT was found to be responsible for this effect [125].

In sheep, the administration of 5-HTP substantially increases serum melatonin through a marked increase in pineal 5-HT and its metabolites, including $N$-acetylserotonin [126], whereas during the natural light period, a promotion of melatonin synthesis in the pineal gland and intestinal tract was found in rumen-protected 5-HTP [127]. In fetal lambs in late 
gestation, systemic infusion of 5-HTP during normoxia greatly increases the incidence of fetal breathing movements [128].

Finally, in the Holstein dairy cow liver, 5-HTP infusions stimulated an autocrineparacrine adaptation to lactation [129].

Figure 10 summarizes some effects of 5-HTP on animals.

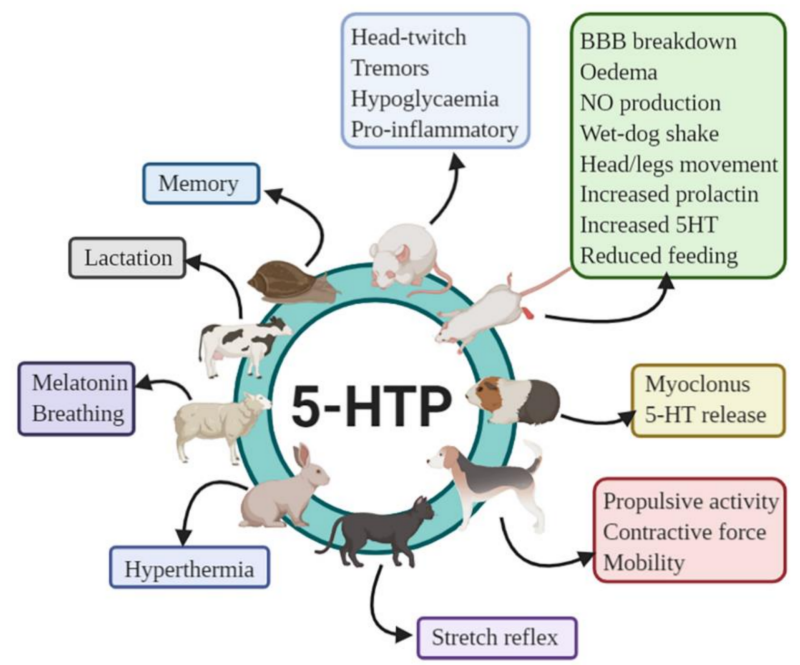

Figure 10. Summary of effects of 5-HTP on some animals. In terrestrial snails, 5-HTP reinstates the context memory, whereas in mice, 5-HTP produces a characteristic head twitch and tremors, induces hypoglycemia, and suppresses inflammation by inducing pro-inflammatory mediators. In rats, most of the listed effects of 5-HTP are dose dependent. In guinea pigs, 5-HTP enhances myoclonus and facilitates the luminal 5-HT release. In dogs, 5-HTP increases propulsive activity, contractive force, and mobility index. Injection of 5-HTP facilitates the stretch reflex in cats and produces a fall in temperature in rabbits. In sheep, 5-HTP increases serum melatonin and foetal breathing movements and stimulates an autocrine-paracrine adaptation to lactation in cows. Created with BioRender.com.

\subsection{Effects of 5-HTP on Humans}

\subsubsection{Serotonin Syndrome}

While on the one side, the lack of serotonin is responsible for several diseases, including depression, its excess may be problematic. Medication-induced serotonergic hyperactivity causes serotonin syndrome, which results from antidepressant medications and is characterized by the triad of altered mental status, autonomic dysfunction, and neuromuscular abnormalities. Serotonin syndrome may lead to misdiagnosis, in a similar way as for neuroleptic malignant syndrome. Serotonin syndrome may eventually result in death; however, supportive care alone is sufficient to recover completely for most of patients. Excessive 5-HTP stimulation is the main pathophysiologic mechanism involved and the use of a serotonin antagonist supports this finding [130]. Serotonin syndrome can trigger other clinical conditions; therefore, in order to detect the syndrome and prevent rapid clinical deterioration, it is important to better understand the molecular context of this condition [131].

\subsubsection{Effect of 5-HTP on Depression, Anxiety, Dystonia, and Panic Disorders}

The amount of endogenous 5-HTP available for serotonin synthesis depends on the availability of tryptophan and the activity of various enzymes, especially TPH, indoleamine 2,3-dioxygenase, and tryptophan 2,3-dioxygenase (TDO) [132]. In depressed patients, tryptophan, serotonin, kynurenine, and their metabolite levels remain unclear. Serotonin is involved in depressive pathophysiology and evidence indicates that the transport of 5-HTP across the blood-brain barrier is compromised in major depression [133], as found in childhood with major depression [134]. Early studies assessed the important 
role of tryptophan and 5-HTP as an antidepressant [135,136], and relatively few adverse effects are associated with its use in the treatment of depressed patients [137]. Among the side effects, the administration of 5-HTP may cause dose-dependent gastrointestinal problems, whereas the combination of 5-HTP with a peripheral decarboxylase inhibitor may cause psychopathological side effects, like acute anxiety [138]. Additionally, vomiting and nausea have been reported when 5-HTP was used at doses above $100 \mathrm{mg}$ [139].

The antidepressant activity appears to be linked to the activation rather than suppression of monoaminergic activity; therefore, the decreased monoamine metabolism found in some types of depression is likely to depend on a primary metabolic deficit rather than receptor hypersensitivity [140]. Decreased serotonergic activity may be present in both depression and mania [141] and the therapeutic effect of 5-HTP has been correlated with an increase in serotonin at central serotonin receptors [142].

Evidence also supports the combined used of 5-HTP with other drugs. In 30 hospitalized patients affected by endogenous depression, the antidepressant action of the combination of nialamide and 5-HTP has been evaluated and compared with a control group which only received nialamide (along with placebo). The combination of nialamide and 5-HTP prompted a fuller recovery in treated patients with respect to those who were treated with nialamide alone [143]. L-deprenil (an irreversible selective MAO-B inhibitor) was used in an open trial study with patients with unipolar and bipolar depression receiving 5-HTP and benzerazide. The combination of L-deprenil and 5-HTP showed a significantly greater clinical improvement in treated patients with respect to placebo patients but not in patients treated with 5-HTP alone [144]. In women experiencing selective serotonin reuptake inhibitor (SSRI)- or serotonin-norepinephrine reuptake inhibitor (SNRIs)-resistant depression, the combination treatment with creatine and 5-HTP proved to be an effective augmentation strategy [145].

5-HT was found to mediate anxiety [146] and showed a moderate reduction of the symptomatology on the 90-item symptoms checklist (SCL-90) and the state scale of the Spielberger State-Trait Anxiety Inventory, suggesting that brain serotonergic pathways are involved in the pathogenesis of anxiety disorders, particularly in agoraphobia and panic disorders [147].

The serotonergic system of the central nervous system might play some role in the pathogenesis of dystonia in hereditary progressive dystonia [148], although results are at odds with the hypothesis that there is a supersensitivity of 5-HT2 receptors in panic disorder [149]. Nevertheless, in panic disorder patients, 5-HTP significantly reduced the reaction to the panic challenge, regarding number of panic attacks, panic symptom score, and subjective anxiety, when compared to placebo [150]. Furthermore, an increased availability of 5-HT may have a gender-dependent protective effect in cholecystokinintetrapeptide-induced panic [151].

\subsubsection{Effect of 5-HTP on Sleep Disorders}

In normal subjects treated with 5-HTP, rapid eye movement (REM) sleep increased from 5 to $53 \%$ of placebo baseline [152] and the effects on sleep were associated with different doses of 5-HTP and the diverse possibilities of metabolic transformation of the precursor [153]. In schizophrenic boys, the administration of 5-HTP was associated with an increase in REM sleep and eye movements [154]; however, in mongoloid infants who received oral 5-HTP for periods extending from 12 to 36 months, 5-HTP failed to induce any long-term differences in the eye movement frequencies. In fact, the drug has a short-term effect lasting up to 8 days and an increase in muscle tone and an improvement of motor behavior were the only long-lasting results [155]. In a group of children with sleep terrors, treatment with 5-HTP was able to modulate the arousal level and to induce a long-term improvement of sleep terrors [156]. Interestingly, it was found that a serotonergic abnormality is involved in affective disorders [157] and direct modulation of the serotonergic system with 5-HTP was useful for the treatment of psychological suffering associated with unreciprocated romantic love [158]. 


\subsubsection{Effects of 5-HTP on Migraine, Ataxia, Fibromyalgia, Alzheimer's, and Parkinson's Disease}

5-HTP was also found to be a treatment of choice in the prophylaxis of migraine $[159,160]$. In subjects who are predisposed to headache, 5-HTP can change the central nervous system (CNS) abnormalities underlying the mechanism of migraine [161]. In another study, two weeks after treatment with 5-HTP, a significant decrease in the number of days with headache was observed [162].

Ataxia is a clinical manifestation indicating dysfunction of the parts of the nervous system that coordinate movement, such as the cerebellum. Some features of cerebellar ataxia have been reported to regress partially with long-term administration of 5-HTP [163], with a significant decrease in the kinetic score, indicating an improvement in coordination, although the effect may sometimes be partial [164].

Lower levels of 5-HTP were found in women with fibromyalgia (FM) in comparison with controls, indicating that the dysregulation of the catecholamine and indolamine pathway in patients with FM may contribute to the physiopathology of this syndrome [165,166]. The treatment with 5-HTP significantly improved all the clinical parameters studied in 50 patients with primary FM syndrome, with only mild and transient side effects reported [167].

Concentrations of 5-HTP are lower in dementia of the Alzheimer's type (DAT) cerebrospinal fluid (CSF) than in a corresponding fraction of control CSF. Therefore, the serotoninergic system is involved in DAT and could be considered for a diagnostic test for DAT [168].

5-HTP has a long history of use as a therapy of Parkinson's disease (PD) $[169,170]$. In Parkinsonian patients, no effects on gastrointestinal absorption of 5-HTP were observed with co-administration of L-dopa with 5-HTP and decarboxylase inhibitors [171]. Moreover, in a single-center, randomized, double-blind, placebo-controlled, cross-over trial, patients receiving placebo and $50 \mathrm{mg}$ of 5-HTP daily over a period of 4 weeks experienced a significant improvement of depressive symptoms during treatment compared with placebo, providing preliminary evidence of the clinical benefit of 5-HTP for treating depressive symptoms in PD [172].

\subsubsection{Effect of 5-HTP on Myoclonus}

5-HTP is useful in the treatment of patients with posthypoxic intention myoclonus [173], palatal myoclonus [174], and cherry red spot-myoclonus syndrome [175]. The administration of 5-HTP and carbidopa dramatically improved the action myoclonus and reduced the amplitude of giant somatosensory evoked potentials [176], whereas the combination of sodium valproate and 5-HTP was useful to control a spinal segmental myoclonus characterized by symmetric, rhythmic contractions of the abdomen [177].

\subsubsection{Effect of 5-HTP on Obesity}

The effect of 5-HTP on feeding behavior, mood state, and weight loss was studied. 5-HTP promoted decreased food intake and weight loss as well as typical anorexia-related symptoms without changes in mood state during the period of observation [178], with a consistent presence of early satiety and a consequent reduction in carbohydrate intake [179]. Moreover, treatment with 5-HTP prompted a decrease in BMI due to an increased feeling of satiety [10].

\subsubsection{Effect of 5-HTP on Prolactin}

Oral administration of 5-HTP significantly increases plasma human prolactin, suggesting that the serotonergic mechanism is involved in the regulation of prolactin secretion in humans [180]. The maximum downregulation of prolactin release occurs when 5-HTP is administered in $4 \mathrm{~h}$ intervals [181] and subacute serotonergic stimulation with oral 5-HTP with the peripheral decarboxylase inhibitor carbidopa resulted in prolactin but not aldosterone release [182]. 


\subsubsection{Antioxidant, Anti-inflammatory, and Analgesic Effects of 5-HTP}

5-HTP also exerts radical scavenging activities. 5-HTP showed higher hydroxyl radical scavenging effects when compared to vitamin C [183] and was also effective on hyperglycemia-induced oxidative stress [184]. Moreover, 5-HTP was found to preserve membrane fluidity in the presence of oxidative stress [185]. 5-HTP significantly reduced tert-butylhydroperoxide-induced oxidative damage in human fibroblast cells and protected these cells against oxidative DNA damage [186]. 5-HTP was also found to inhibit the lipopolysaccharide (LPS)-induced expression of NO and interleukine-6 (IL-6), playing a role in extracellular signal-regulated protein kinase (ERK) activation, cyclooxygenase-2 (COX-2,) and LPS-induced inducible nitric oxide synthase (iNOS). By acting as a reactive oxygen species (ROS) scavenger, 5-HTP has the potential for use in the treatment of inflammatory diseases and as an analgesic [187].

Figure 11 summarizes some effects of 5-HTP on humans.

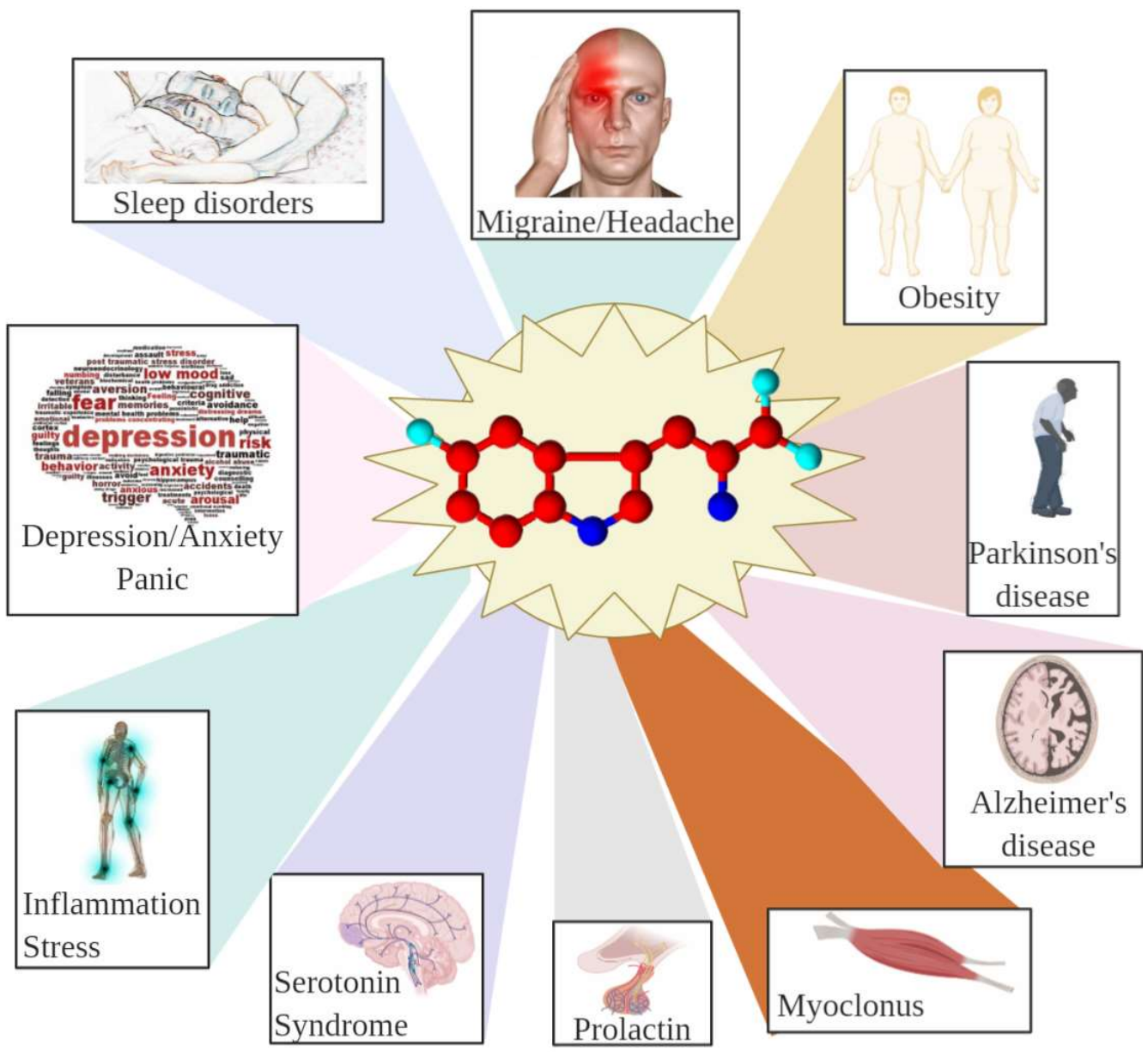

Figure 11. Summary of some effects of 5-HTP on humans. 5-HTP is a treatment of choice in the prophylaxis of migraine and headache and promotes decreased food intake and weight loss in obese patients. 5-HTP is used for treating depressive symptoms in Parkinson's disease and may be used as a diagnostic test for Alzheimer's disease. 5-HTP is useful to control some forms of myoclonus and significantly increases plasma human prolactin. Excessive 5-HTP generates serotonin syndrome. 5-HTP has the potential for use in the treatment of inflammatory diseases and oxidative stress. As a precursor of 5-HT, 5-HTP treatment is used to reduce depression, anxiety, and panic attacks. 5-HTP is associated with an increase in rapid eye movement (REM) sleep and reduces sleep disorder. Created with BioRender.com. 


\section{Toxicology of 5-HTP}

An excess of 5-HTP may be responsible for serotonin syndrome (see Section 8.2.1) and an excessive treatment was found to be associated with severe side effects, including behavioral disturbances, abnormal mental functions, and intolerance. Clinically relevant ingestion of 5-HTP in dogs was found to result in a potentially life-threatening syndrome resembling serotonin syndrome in humans, which requires prompt and aggressive care [188]. After 5-HTP administration, the endogenous serotonin levels increased by fourfold in the rat plasma and brain, associated with profound hyperthermia, oxidative stress, and NO upregulation [106].

Toxicity issues have also been raised in 5-HTP. The use of L-tryptophan, the precursor of 5-HTP, as a dietary supplement was suspended in 1989 due to the occurrence of eosinophilia-myalgia syndrome (EMS), a rare, sometimes fatal neurological condition including debilitating myalgia and marked peripheral eosinophilia, that was traced to contaminated synthetic tryptophan from a single manufacturer (Showa Denko) [189,190]. Therefore, 5-HTP has been under vigilance by consumers, industry, academia, and government for its safety. With the possible exception of one unresolved case of a Canadian woman, no definitive cases of toxicity have emerged despite the worldwide usage of 5-HTP for the last 20 years. Neither toxic contaminants similar to those associated with L-tryptophan, nor the presence of any other significant impurities have been detected in several sources of 5-HTP. Speculations concerning the chemistry and toxicity of infinitesimal concentrations of a minor chromatographic peak (peak X) found in some 5-HTP samples lack credibility, due to possible chromatographic artifacts [5]. Further studies found no significant evidence of EMS in rats receiving high-dose 5-HTP for 1 year [191]. Based on accurate mass, tandem mass spectrometric analysis, and comparison with authentic standard compound analysis, peak X was determined to be 4,5-tryptophan-dione, a putative neurotoxin. Because 4,5-tryptophan-dione was found in case-implicated 5-HTP as well as six over the counter samples, some cause for concern in terms of the safety of such commercial preparations of 5-HTP was raised [7]. Indeed, it was demonstrated that samples of commercially available 5-HTP analyzed by HPLC-MS contained three or more contaminants of the peak $X$ family [8]. Two other 5-HTP contaminants, peak E $\left(1,1^{\prime}\right.$-ethylidenebis(L-tryptophan)) and peak-UV5 (3-anilinoalanine), were found to contribute to the pathogenesis of EMS, or may be surrogates for other chemicals that induce EMS [192-194]. Another contaminant of tryptophan, peak AAA, was defined as a statistical contaminant and was identified as two distinct isomers: peak AA(1) as (S)-2amino-3-(2((S,E)-7-methylnon-1-en-1-yl)-1H-indol-3-yl) propanoic acid and peak AAA(2) as (S)-2-amino-3-(2-((E)-dec-1-en-1-yl)-1H-indol-3-yl) propanoic acid [6]. Interestingly, after replacement with 5-HTP not containing impurities, eosinophilia was resolved [195].

\section{Conclusions}

The use of 5-HTP dates back to the first half of the $20^{\text {th }}$ century, where it was recognized as an important precursor of the neurotransmitter serotonin. Its use increased after the discovery of some toxic impurities in commercial tryptophan, although further analyses also found similar impurities in 5-HTP preparation. The main application of 5-HTP is as a support for serotonin depletion and is considered an interesting alternative to the use of SSRIs. The main natural source of 5-HTP is the seeds of the African plant Griffonia simplicifolia, which also produces interesting $\beta$-carboline alkaloid derivatives. However, the seasonal and regional variations of this plant limit the output of 5-HTP. For this reason, recent biotechnological approaches have been developed by using recombinant genes and genetic engineering of both bacteria (mainly E. coli) and yeasts, for the economically and environmentally sustainable production of 5-HTP. These methods are based on biochemical reactions (such as TPH catalysis) and the use of alternative cofactors to improve the biosynthetic ability of bacterial and fungal cells to produce 5-HTP at industrial levels. While on the one side, the use of 5-HTP may be not recommended in humans (as in the case of serotonin syndrome), on the other, the molecule (drug or dietary supplement) 
has been proved to be effective to treat neurological and metabolic diseases. The majority of clinical trials are on depression, anxiety, panic attacks, and sleep disorders; however, the molecule has been demonstrated to be a promising support to reduce food/feed intake and to be potentially used for metabolic diseases like obesity and diabetes. A few studies also indicate its potential in neurodegenerative diseases like Alzheimer's and Parkinson's disease. Future developments are focused on safer 5-HTP production. The improvement of 5-HTP yield and the removal of toxic impurities by biotechnological transformation will allow a sustainable and safer 5-HTP production for both pharmaceutical and nutraceutical industries.

Supplementary Materials: The following are available online at https://www.mdpi.com/1422-006 7/22/1/181/s1, Supplementary File S1, EndNote zipped file containing the 816 selected references.

Author Contributions: Conceptualization; writing; funding acquisition, M.E.M. All authors have read and agreed to the published version of the manuscript.

Funding: This research was funded by the University of Turin local research grants to M.E.M.

Conflicts of Interest: The author declares no conflict of interest.

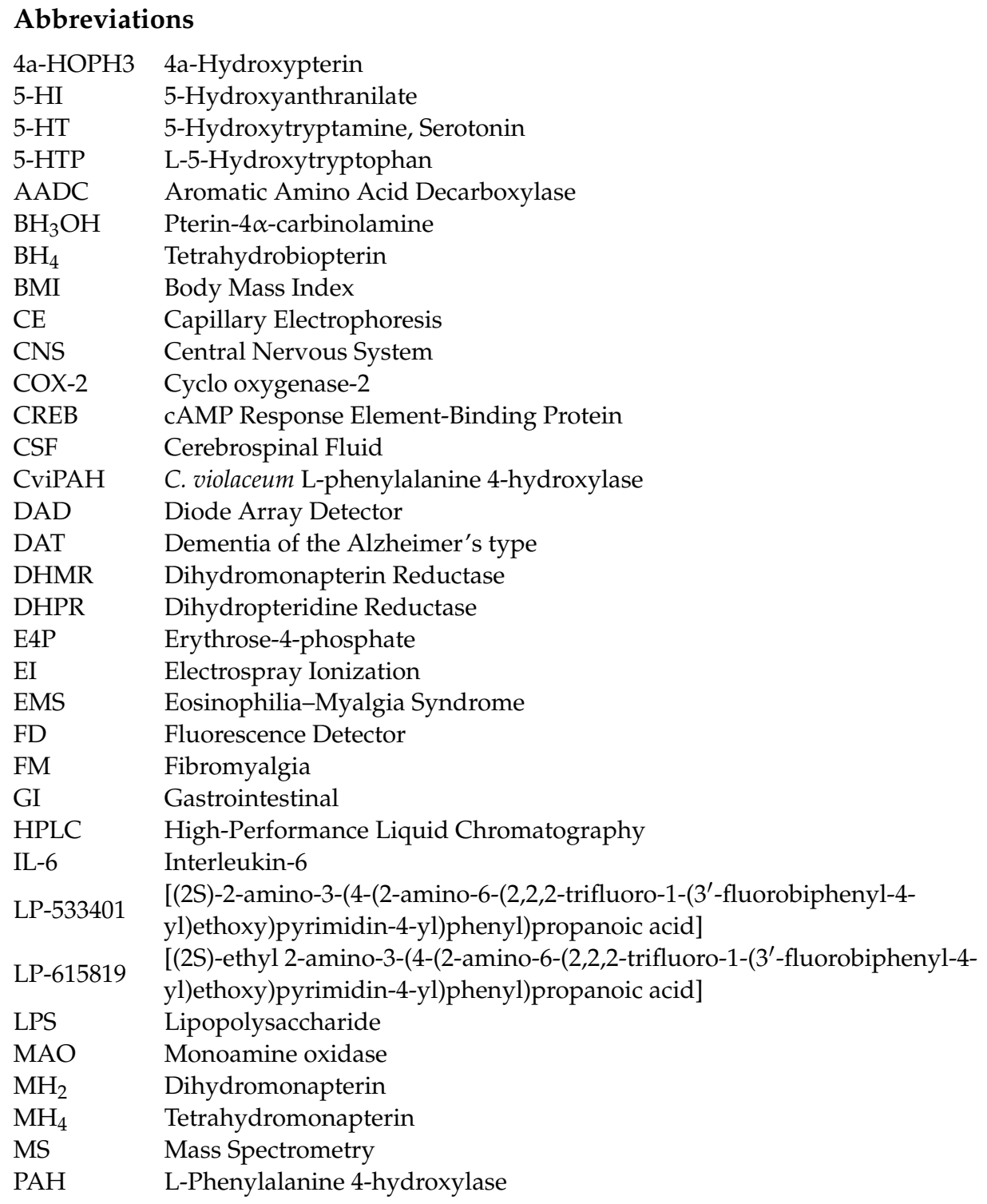




$\begin{array}{ll}\text { PCD } & \text { Pterin-4 } \alpha \text {-carbinolamine Dehydratase } \\ \text { PD } & \text { Parkinson's Disease } \\ \text { Peak AAA1 } & \text { (S)-2-amino-3-(2((S,E)-7-methylnon-1-en-1-yl)-1H-indol-3-yl) propanoic acid } \\ \text { Peak AAA2 } & (\text { S)-2-amino-3-(2-(E)-dec-1-en-1-yl)-1H-indol-3-yl) propanoic acid } \\ \text { Peak E } & {\left[1,1^{\prime} \text {-Ethylidenebis(L-tryptophan)] }\right.} \\ \text { Peak X } & \text { 4,5-Tryptophan-dione } \\ \text { Peak-UV5 } & \text { 3-anilinoalanine } \\ \text { PEP } & \text { Phosphoenol Pyruvate } \\ \text { p-EPA } & \text { p-Ethynylphenylalanine } \\ \text { PKA } & \text { Protein Kinase A } \\ \text { PTPS } & \text { 6-Pyruvate-tetrahydropterin Synthase } \\ \text { REM } & \text { Rapid Eye Movement } \\ \text { RFLP } & \text { Restriction Fragment Length Polymorphism } \\ \text { ROS } & \text { Reactive Oxygen Species } \\ \text { SalABCD } & \text { Salicylate 5-hydroxylase } \\ \text { SCL-90 } & \text { 90-Item Symptoms Checklist } \\ \text { SIM } & \text { Selective Ion Monitoring } \\ \text { SNRI } & \text { Serotonin-Norepinephrine Reuptake Inhibitor } \\ \text { SPR } & \text { Sepiapterin Reductase } \\ \text { SSRI } & \text { Selective Serotonin Reuptake Inhibitor } \\ \text { TCM } & \text { Traditional Chinese Medicine } \\ \text { TDO } & \text { Tryptophan 2,3-dioxygenase } \\ \text { TPH } & \text { Tryptophan Hydroxylase } \\ \text { TrpEfbr G } & \text { Anthranilate Synthase } \\ \text { Trp-P-1 } & \text { 3-amino-1,4-dimethyl-5H-pyrido[4,3-b]indole } \\ \text { Trp-P-2 } & \text { 3-Amino-1-methyl-5H-pyrido[4,3-b]indole } \\ & \end{array}$

\section{References}

1. Strac, D.S.; Pivac, N.; Muck-Seler, D. The serotonergic system and cognitive function. Transl. Neurosci. 2016, 7, 35-49.

2. Ye, T.T.; Yin, X.M.; Yu, L.; Zheng, S.J.; Cai, W.J.; Wu, Y.; Feng, Y.Q. Metabolic analysis of the melatonin biosynthesis pathway using chemical labeling coupled with liquid chromatography-mass spectrometry. J. Pineal Res. 2019, 66, 11. [CrossRef] [PubMed]

3. Samanta, S. Physiological and pharmacological perspectives of melatonin. Arch. Physiol. Biochem. 2020, 1-22. [CrossRef] [PubMed]

4. Walther, D.J.; Bader, M. A unique central tryptophan hydroxylase isoform. Biochem. Pharmacol. 2003, 66, 1673-1680. [CrossRef]

5. Das, Y.T.; Bagchi, M.; Bagchi, D.; Preuss, H.G. Safety of 5-hydroxy-1-tryptophan. Toxicol. Lett. 2004, 150, 111-122. [CrossRef]

6. Klarskov, K.; Gagnon, H.; Boudreault, P.L.; Normandin, C.; Plancq, B.; Marsault, E.; Gleich, G.J.; Naylor, S. Structure determination of disease associated peak aaa from 1-tryptophan implicated in the eosinophilia-myalgia syndrome. Toxicol. Lett. 2018, 282, 71-80. [CrossRef]

7. Klarskov, K.; Johnson, K.L.; Benson, L.M.; Cragun, J.D.; Gleich, G.J; Wrona, M.; Jiang, X.R.; Dryhurst, G.; Naylor, S. Structural characterization of a case-implicated contaminant, "peak x," in commercial preparations of 5-hydroxytryptophan. J. Rheumatol. 2003, 30, 89-95.

8. Klarskov, K.; Johnson, K.L.; Benson, L.M.; Gleich, G.J.; Naylor, S. Eosinophilia-myalgia syndrome case-associated contaminants in commercially available 5-hydroxytryptophan. In Tryptophan, Serotonin and Melatonin: Basic Aspects and Applications; Huether, G., Kochen, W., Simat, T.J., Steinhart, H., Eds.; Springer: New York, NY, USA, 1999; pp. 461-468.

9. Esposito, M.; Precenzano, F.; Sorrentino, M.; Avolio, D.; Carotenuto, M. A medical food formulation of griffonia simplicifolia/magnesium for childhood periodic syndrome therapy: An open-label study on motion sickness. J. Med. Food 2015, 18, 916-920. [CrossRef]

10. Rondanelli, M.; Opizzi, A.; Faliva, M.; Bucci, M.; Perna, S. Relationship between the absorption of 5-hydroxytryptophan from an integrated diet, by means of griffonia simplicifolia extract, and the effect on satiety in overweight females after oral spray administration. Eat. Weight Disord. Stud. Anorex. Bulim. Obes. 2012, 17, E22-E28.

11. Carnevale, G.; Di Viesti, V.; Zavatti, M.; Benelli, A.; Zanoli, P. Influence of griffonia simplicifolia on male sexual behavior in rats: Behavioral and neurochemical study. Phytomedicine 2011, 18, 947-952. [CrossRef]

12. Carnevale, G.; Di Viesti, V.; Zavatti, M.; Zanoli, P. Anxiolytic-like effect of griffonia simplicifolia baill. Seed extract in rats. Phytomedicine 2011, 18, 848-851. [CrossRef] [PubMed]

13. Babu, S.K.; Ramakrishna, T.; Subbaraju, G.V. Hplc estimation of 5-hydroxytryptophan in griffonia simplicifolia extracts. Asian J. Chem. 2005, 17, 506-510.

14. Lemaire, P.A.; Adosraku, R.K. An hplc method for the direct assay of the serotonin precursor, 5-hydroxytrophan, in seeds of griffonia simplicifolia. Phytochem. Anal. 2002, 13, 333-337. [CrossRef] [PubMed] 
15. Vigliante, I.; Mannino, G.; Maffei, M.E. Chemical characterization and DNA fingerprinting of griffonia simplicifolia baill. Molecules 2019, 24, 1032. [CrossRef] [PubMed]

16. Glinwood, R.; Pettersson, J.; Ahmed, E.; Ninkovic, V.; Birkett, M.; Pickett, J. Change in acceptability of barley plants to aphids after exposure to allelochemicals from couch-grass (elytrigia repens). J. Chem. Ecol. 2003, 29, 261-274. [CrossRef] [PubMed]

17. Hagin, R.D. Isolation and identification of 5-hydroxyindole-3-acetic acid and 5-hydroxytryptophan, major allelopathic aglycons in quackgrass (agropyron-repens 1 beauv). J. Agric. Food Chem. 1989, 37, 1143-1149. [CrossRef]

18. Murch, S.J.; KrishnaRaj, S.; Saxena, P.K. Tryptophan is a precursor for melatonin and serotonin biosynthesis in in vitro regenerated st. John's wort (hypericum perforatum 1. Cv. Anthos) plants. Plant Cell Rep. 2000, 19, 698-704. [CrossRef]

19. Fernandez-Cruz, E.; Cerezo, A.B.; Cantos-Villar, E.; Troncoso, A.M.; Garcia-Parrilla, M.C. Time course of l-tryptophan metabolites when fermenting natural grape musts: Effect of inoculation treatments and cultivar on the occurrence of melatonin and related indolic compounds. Aust. J. Grape Wine Res. 2019, 25, 92-100. [CrossRef]

20. Diamante, M.S.; Borges, C.V.; da Silva, M.B.; Minatel, I.O.; Correa, C.R.; Gomez, H.A.G.; Lima, G.P.P. Bioactive amines screening in four genotypes of thermally processed cauliflower. Antioxidants 2019, 8, 311. [CrossRef]

21. Lysek, N.; Kinscherf, R.; Claus, R.; Lindel, T. L-5-hydroxytryptophan: Antioxidant and anti-apoptotic principle of the intertidal sponge hymeniacidon heliophila. Z. Fur Nat. C J. Biosci. 2003, 58, 568-572. [CrossRef]

22. Muszynska, B.; Sulkowska-Ziaja, K.; Ekiert, H. Indole compounds in fruiting bodies of some edible basidiomycota species. Food Chem. 2011, 125, 1306-1308. [CrossRef]

23. Muszynska, B.; Sulkowska-Ziaja, K.; Ekiert, H. Analysis of indole compounds in methanolic extracts from the fruiting bodies of cantharellus cibarius (the chanterelle) and from the mycelium of this species cultured in vitro. J. Food Sci. Technol. Mysore 2013, 50, 1233-1237. [CrossRef] [PubMed]

24. Gurevich, L.S. Indole-derivatives in certain panaeolus species from east europe and siberia. Mycol. Res. 1993, 97, 251-254. [CrossRef]

25. Koppisetti, G.; Siriki, A.; Sukala, K.; Subbaraju, G.V. Estimation of 1-5-hydroxytryptophan in rat serum and griffonia seed extracts by liquid chromatography-mass spectrometry. Anal. Chim. Acta 2005, 549, 129-133. [CrossRef]

26. Guillen-Casla, V.; Rosales-Conrado, N.; Leon-Gonzalez, M.E.; Perez-Arribas, L.V.; Polo-Diez, L.M. Determination of serotonin and its precursors in chocolate samples by capillary liquid chromatography with mass spectrometry detection. J. Chromatogr. A 2012, 1232, 158-165. [CrossRef] [PubMed]

27. Magnussen, I. Effects of carbidopa on the cerebral accumulation of exogenous 1-5-hydroxytryptophan in mice. Acta Pharm. Toxicol. (Copenh) 1984, 55, 199-202. [CrossRef]

28. Boulet, L.; Faure, P.; Flore, P.; Monteremal, J.; Ducros, V. Simultaneous determination of tryptophan and 8 metabolites in human plasma by liquid chromatography/tandem mass spectrometry. J. Chromatogr. B Anal. Technol. Biomed. Life Sci. 2017, 1054, 36-43. [CrossRef]

29. Konieczna, L.; Roszkowska, A.; Niedzwiecki, M.; Baczek, T. Hydrophilic interaction chromatography combined with dispersive liquid-liquid microextraction as a preconcentration tool for the simultaneous determination of the panel of underivatized neurotransmitters in human urine samples. J. Chromatogr. A 2016, 1431, 111-121. [CrossRef]

30. Morgan, L.D.; Baker, H.; Yeoman, M.S.; Patel, B.A. Chromatographic assay to study the activity of multiple enzymes involved in the synthesis and metabolism of dopamine and serotonin. Analyst 2012, 137, 1409-1415. [CrossRef]

31. Fickbohm, D.J.; Lynn-Bullock, C.P.; Spitzer, N.; Caldwell, H.K.; Katz, P.S. Localization and quantification of 5-hydroxytryptophan and serotonin in the central nervous systems of tritonia and aplysia. J. Comp. Neurol. 2001, 437, 91-105. [CrossRef]

32. Coelho, A.G.; Aguiar, F.P.C.; de Jesus, D.P. A rapid and simple method for determination of 5-hydroxytryptophan in dietary supplements by capillary electrophoresis. J. Braz. Chem. Soc. 2014, 25, 783-787. [CrossRef]

33. Peterson, Z.D.; Lee, M.L.; Graves, S.W. Determination of serotonin and its precursors in human plasma by capillary electrophoresiselectrospray ionization-time-of-flight mass spectrometry. J. Chromatogr. B Anal. Technol. Biomed. Life Sci. 2004, 810, 101-110. [CrossRef]

34. Wise, D.D.; Shear, J.B. Quantitation of nicotinamide and serotonin derivatives and detection of flavins in neuronal extracts using capillary electrophoresis with multiphoton-excited fluorescence. J. Chromatogr. A 2006, 1111, 153-158. [CrossRef] [PubMed]

35. Qiao, C.D.; Song, P.S.; Yan, X.; Jiang, S.X. Separation of biogenic amines by micellar electrokinetic chromatography. Chin. J. Anal. Chem. 2007, 35, 95-98.

36. Shi, H.M.; Wang, B.; Niu, L.M.; Cao, M.S.; Kang, W.J.; Lian, K.Q.; Zhang, P.P. Trace level determination of 5-hydroxytryptamine and its related indoles in amniotic fluid by gas chromatography-mass spectrometry. J. Pharm. Biomed. Anal. 2017, 143, 176-182. [CrossRef]

37. Hinterholzer, A.; Stanojlovic, V.; Regl, C.; Huber, C.G.; Cabrele, C.; Schubert, M. Identification and quantification of oxidation products in full-length biotherapeutic antibodies by nmr spectroscopy. Anal. Chem. 2020, 92, 9666-9673. [CrossRef]

38. Kuo, T.R.; Chen, J.S.; Chiu, Y.C.; Tsai, C.Y.; Hu, C.C.; Chen, C.C. Quantitative analysis of multiple urinary biomarkers of carcinoid tumors through gold-nanoparticle-assisted laser desorption/ionization time-of-flight mass spectrometry. Anal. Chim. Acta 2011, 699, 81-86. [CrossRef]

39. Bisby, R.H.; Arvanitidis, M.; Botchway, S.W.; Clark, I.P.; Parker, A.W.; Tobin, D. Investigation of multiphoton-induced fluorescence from solutions of 5-hydroxytryptophan. Photochem. Photobiol. Sci. 2003, 2, 157-162. [CrossRef] 
40. Tunna, I.J.; Patel, B.A. Analysis of 5-hydroxytryptophan in the presence of excipients from dietary capsules: Comparison between cyclic voltammetry and uv visible spectroscopy. Anal. Methods 2013, 5, 2523-2528. [CrossRef]

41. Chen, Y.H.; Li, G.K.; Hu, Y.F. A sensitive electrochemical method for the determination of 5-hydroxytryptophan in rats' brain tissue based on a carbon nanosheets-modified electrode. Anal. Methods 2015, 7, 1971-1976. [CrossRef]

42. Ranganathan, D.; Zamponi, S.; Berrettoni, M.; Mehdi, B.L.; Cox, J.A. Oxidation and flow-injection amperometric determination of 5-hydroxytryptophan at an electrode modified by electrochemically assisted deposition of a sol-gel film with templated nanoscale pores. Talanta 2010, 82, 1149-1155. [CrossRef] [PubMed]

43. Kalachar, H.C.B.; Arthoba Naik, Y.; Basavanna, S.; Viswanatha, R.; Venkatesha, T.G.; Sheela, T. Amperometric and differential pulse voltammetric determination of 5-hydroxy-l-tryptophan in pharmaceutical samples using gold modified pencil graphite electrode. J. Chem. Pharm. Res. 2011, 3, 530-539.

44. Chen, L.; Lian, H.T.; Sun, X.Y.; Liu, B. Sensitive detection of 1-5-hydroxytryptophan based on molecularly imprinted polymers with graphene amplification. Anal. Biochem. 2017, 526, 58-65. [CrossRef] [PubMed]

45. Kumar, N.; Goyal, R.N. Simultaneous determination of melatonin and 5-hydroxytrptophan at the disposable poly(melamine)/poly-(o-aminophenol) composite modified screen printed sensor. J. Electro. Anal. Chem. 2020, 874, 114458. [CrossRef]

46. Kumar, N.; Sharma, R.; Goyal, R.N. Palladium nano particles decorated multi-walled carbon nanotubes modified sensor for the determination of 5-hydroxytryptophan in biological fluids. Sens. Actuators B Chem. 2017, 239, 1060-1068. [CrossRef]

47. Li, M.D.; Tseng, W.L.; Cheng, T.L. Ultrasensitive detection of indoleamines by combination of nanoparticle-based extraction with capillary electrophoresis/laser-induced native fluorescence. J. Chromatogr. A 2009, 1216, 6451-6458. [CrossRef]

48. Shahrokhian, S.; Bayat, M. Pyrolytic graphite electrode modified with a thin film of a graphite/diamond nano-mixture for highly sensitive voltammetric determination of tryptophan and 5-hydroxytryptophan. Microchim. Acta 2011, 174, 361-366. [CrossRef]

49. Seo, K.D.; Hossain, M.M.D.; Gurudatt, N.G.; Choi, C.S.; Shiddiky, M.J.A.; Park, D.S.; Shim, Y.B. Microfluidic neurotransmitters sensor in blood plasma with mediator-immobilized conducting polymer/n, s-doped porous carbon composite. Sens. Actuators B Chem. 2020, 313, 128017. [CrossRef]

50. Hamlin, K.E.; Fischer, F.E. The synthesis of 5-hydroxytryptamine. J. Am. Chem. Soc. 1951, 73, 5007-5008. [CrossRef]

51. Ek, A.; Witkop, B. The synthesis of labile hydroxytryptophan metabolites1. J. Am. Chem. Soc. 1954, 76, 5579-5588. [CrossRef]

52. Snyder, H.R.; Smith, C.W. A convenient synthesis of dl-tryptophan. J. Am. Chem. Soc. 1944, 66, 350-351. [CrossRef]

53. Koo, J.; Avakian, S.; Martin, G.J. Synthesis in the 5-hydroxyindole series. N-acetyl-5-hydroxytryptophan and related compounds. J. Org. Chem. 1959, 24, 179-183. [CrossRef]

54. Frangatos, G.; Chubb, F.L. A new synthesis of 5-hydroxytryptophan. Can. J. Chem. 1959, 37, 1374-1376. [CrossRef]

55. Moe, O.A.; Warner, D.T. 1,4-addition reactions. I. The addition of acylamidomalonates to acrolein1a. J. Am. Chem. Soc. 1948, 70, 2763-2765. [CrossRef]

56. Fitzpatrick, P.F. Tetrahydropterin-dependent amino acid hydroxylases. Annu. Rev. Biochem. 1999, 68, 355-381. [CrossRef] [PubMed]

57. Eser, B.E.; Barr, E.W.; Frantorn, P.A.; Saleh, L.; Bollinger, J.M.; Krebs, C.; Fitzpatrick, P.F. Direct spectroscopic evidence for a high-spin fe(iv) intermediate in tyrosine hydroxylase. J. Am. Chem. Soc. 2007, 129, 11334. [CrossRef] [PubMed]

58. Pavon, J.A.; Eser, B.; Huynh, M.T.; Fitzpatrick, P.F. Single turnover kinetics of tryptophan hydroxylase: Evidence for a new intermediate in the reaction of the aromatic amino acid hydroxylases. Biochemistry 2010, 49, 7563-7571. [CrossRef] [PubMed]

59. Hara, R.; Kino, K. Enhanced synthesis of 5-hydroxy-l-tryptophan through tetrahydropterin regeneration. AMB Express 2013, 3, 7. [CrossRef]

60. Wang, H.J.; Liu, W.Q.; Shi, F.; Huang, L.; Lian, J.Z.; Qu, L.; Cai, J.; Xu, Z.A. Metabolic pathway engineering for high-level production of 5-hydroxytryptophan in escherichia coli. Metab. Eng. 2018, 48, 279-287. [CrossRef]

61. Yamamoto, K.; Kataoka, E.; Miyamoto, N.; Furukawa, K.; Ohsuye, K.; Yabuta, M. Genetic engineering of escherichia coli for production of tetrahydrobiopterin. Metab. Eng. 2003, 5, 246-254. [CrossRef]

62. Moran, G.R.; Fitzpatrick, P.F. A continuous fluorescence assay for tryptophan hydroxylase. Anal. Biochem. 1999, $266,148-152$. [CrossRef] [PubMed]

63. Flatmark, T.; Stevens, R.C. Structural insight into the aromatic amino acid hydroxylases and their disease-related mutant forms. Chem. Rev. 1999, 99, 2137-2160. [CrossRef] [PubMed]

64. Ehret, M.; Cash, C.D.; Hamon, M.; Maitre, M. Formal demonstration of the phosphorylation of rat brain tryptophan hydroxylase by ca2+/calmodulin-dependent protein kinase. J. Neurochem. 1989, 52, 1886-1891. [CrossRef] [PubMed]

65. Matthes, S.; Bader, M. Peripheral serotonin synthesis as a new drug target. Trends Pharmacol. Sci. 2018, 39, 560-572. [CrossRef] [PubMed]

66. Hoglund, E.; Overli, O.; Winberg, S. Tryptophan metabolic pathways and brain serotonergic activity: A comparative review. Front. Endocrinol. 2019, 10, 158. [CrossRef]

67. Sakowski, S.A.; Geddes, T.J.; Thomas, D.M.; Levi, E.; Hatfield, J.S.; Kuhn, D.M. Differential tissue distribution of tryptophan hydroxylase isoforms 1 and 2 as revealed with monospecific antibodies. Brain Res. 2006, 1085, 11-18. [CrossRef]

68. Ota, M.; Dostert, P.; Hamanaka, T.; Nagatsu, T.; Naoi, M. Inhibition of tryptophan hydroxylase by (r)- and (s)-1-methyl-6,7dihydroxy-1,2,3,4-tetrahydroisoquinolines (salsolinols). Neuropharmacology 1992, 31, 337-341. [CrossRef] 
69. Kim, E.I.; Kang, M.H.; Lee, M.K. Inhibitory effects of tetrahydropapaverine on serotonin biosynthesis in murine mastocytoma p815 cells. Life Sci. 2004, 75, 1949-1957. [CrossRef]

70. Naoi, M.; Hosoda, S.; Ota, M.; Takahashi, T.; Nagatsu, T. Inhibition of tryptophan hydroxylase by food-derived carcinogenic heterocyclic amines, 3-amino-1-methyl-5h-pyrido[4,3-b]indole and 3-amino-1,4-dimethyl-5h-pyrido[4,3-b]indole. Biochem. Pharmacol. 1991, 41, 199-203. [CrossRef]

71. Zimmer, L.; Luxen, A.; Giacomelli, F.; Pujol, J.F. Short- and long-term effects of p-ethynylphenylalanine on brain serotonin levels. Neurochem. Res. 2002, 27, 269-275. [CrossRef]

72. Liu, Q.Y.; Yang, Q.; Sun, W.M.; Vogel, P.; Heydorn, W.; Yu, X.Q.; Hu, Z.X.; Yu, W.S.; Jonas, B.; Pineda, R.; et al. Discovery and characterization of novel tryptophan hydroxylase inhibitors that selectively inhibit serotonin synthesis in the gastrointestinal tract. J. Pharmacol. Exp. Ther. 2008, 325, 47-55. [CrossRef] [PubMed]

73. Cianchetta, G.; Stouch, T.; Yu, W.; Shi, Z.C.; Tari, L.W.; Swanson, R.V.; Hunter, M.J.; Hoffman, I.D.; Liu, Q. Mechanism of inhibition of novel tryptophan hydroxylase inhibitors revealed by co-crystal structures and kinetic analysis. Curr. Chem. Genom. 2010, 4, 19-26. [CrossRef] [PubMed]

74. Markham, A. Telotristat ethyl: First global approval. Drugs 2017, 77, 793-798. [CrossRef] [PubMed]

75. Goldberg, D.R.; De Lombaert, S.; Aiello, R.; Bourassa, P.; Barucci, N.; Zhang, Q.; Paralkar, V.; Stein, A.J.; Valentine, J.; Zavadoski, W. Discovery of acyl guanidine tryptophan hydroxylase-1 inhibitors. Bioorganic Med. Chem. Lett. 2016, 26, 2855-2860. [CrossRef]

76. Goldberg, D.R.; De Lombaert, S.; Aiello, R.; Bourassa, P.; Barucci, N.; Zhang, Q.; Paralkar, V.; Stein, A.J.; Holt, M.; Valentine, J.; et al. Optimization of spirocyclic proline tryptophan hydroxylase-1 inhibitors. Bioorganic Med. Chem. Lett. 2017, 27, 413-419. [CrossRef]

77. Shi, H.; Cui, Y.; Qin, Y. Discovery and characterization of a novel tryptophan hydroxylase 1 inhibitor as a prodrug. Chem. Biol. Drug Des. 2018, 91, 202-212. [CrossRef]

78. Barbosa, R.; Scialfa, J.H.; Terra, I.M.; Cipolla-Neto, J.; Simonneaux, V.; Afeche, S.C. Tryptophan hydroxylase is modulated by 1-type calcium channels in the rat pineal gland. Life Sci. 2008, 82, 529-535. [CrossRef]

79. Braga, A.; Faria, N. Bioprocess optimization for the production of aromatic compounds with metabolically engineered hosts: Recent developments and future challenges. Front. Bioeng. Biotechnol. 2020, 8, 18. [CrossRef]

80. Xu, P.; Gu, Q.; Wang, W.Y.; Wong, L.; Bower, A.G.W.; Collins, C.H.; Koffas, M.A.G. Modular optimization of multi-gene pathways for fatty acids production in e. Coli. Nat. Commun. 2013, 4, 1409. [CrossRef]

81. Li, L.; Liu, Z.; Jiang, H.; Mao, X.Z. Biotechnological production of lycopene by microorganisms. Appl. Microbiol. Biotechnol. 2020, 104, 10307-10324. [CrossRef]

82. Chen, X.X.; Zhang, C.Q.; Lindley, N.D. Metabolic engineering strategies for sustainable terpenoid flavor and fragrance synthesis. J. Agric. Food Chem. 2020, 68, 10252-10264. [CrossRef] [PubMed]

83. Anarat-Cappillino, G.; Sattely, E.S. The chemical logic of plant natural product biosynthesis. Curr. Opin. Plant Biol. 2014, 19, 51-58. [CrossRef] [PubMed]

84. Mitoma, C.; Weissbach, H.; Udenfriend, S. 5-hydroxytryptophan formation and tryptophan metabolism in chromobacterium violaceum. Arch. Biochem. Biophys. 1956, 63, 122-130. [CrossRef]

85. Letendre, C.H.; Dickens, G.; Guroff, G. The tryptophan hydroxylase of chromobacterium violaceum. J. Biol. Chem. 1974, 249, 7186-7191. [PubMed]

86. Kino, K.; Hara, R.; Nozawa, A. Enhancement of 1-tryptophan 5-hydroxylation activity by structure-based modification of 1-phenylalanine 4-hydroxylase from chromobacterium violaceum. J. Biosci. Bioeng. 2009, 108, 184-189. [CrossRef] [PubMed]

87. Pribat, A.; Blaby, I.K.; Lara-Nunez, A.; Gregory, J.F.; de Crecy-Lagard, V.; Hanson, A.D. Folx and folm are essential for tetrahydromonapterin synthesis in escherichia coli and pseudomonas aeruginosa. J. Bacteriol. 2010, 192, 475-482. [CrossRef]

88. Lin, Y.H.; Sun, X.X.; Yuan, Q.P.; Yan, Y.J. Engineering bacterial phenylalanine 4-hydroxylase for microbial synthesis of human neurotransmitter precursor 5-hydroxytryptophan. Acs Synth. Biol. 2014, 3, 497-505. [CrossRef]

89. Mora-Villalobos, J.A.; Zeng, A.P. Synthetic pathways and processes for effective production of 5-hydroxytryptophan and serotonin from glucose in escherichia coli. J. Biol. Eng. 2018, 12, 3. [CrossRef]

90. Sun, X.X.; Lin, Y.H.; Yuan, Q.P.; Yan, Y.J. Precursor-directed biosynthesis of 5-hydroxytryptophan using metabolically engineered e. Coli. Acs Synth. Biol. 2015, 4, 554-558. [CrossRef]

91. Luo, H.; Schneider, K.; Christensen, U.; Lei, Y.; Herrgard, M.J.; Palsson, B.O. Microbial synthesis of human-hormone melatonin at gram scales. Acs Synth. Biol. 2020, 9, 1240-1245. [CrossRef]

92. Xu, D.; Fang, M.J.; Wang, H.J.; Huang, L.; Xu, Q.Y.; Xu, Z.N. Enhanced production of 5-hydroxytryptophan through the regulation of l-tryptophan biosynthetic pathway. Appl. Microbiol. Biotechnol. 2020, 104, 2481-2488. [CrossRef] [PubMed]

93. Zhang, J.T.; Wu, C.C.; Sheng, J.Y.; Feng, X.Y. Molecular basis of 5-hydroxytryptophan synthesis in saccharomyces cerevisiae. Mol. Biosyst. 2016, 12, 1432-1435. [CrossRef] [PubMed]

94. Smith, A.N.; Black, J.W.; Fisher, E.W. Inhibitory effect of 5-hydroxytryptophan on acid gastric secretion. Nature 1957, $180,1127$. [CrossRef] [PubMed]

95. Bulbring, E.; Lin, R.C. The effect of intraluminal application of 5-hydroxytryptamine and 5-hydroxytryptophan on peristalsis; the local production of 5-ht and its release in relation to intraluminal pressure and propulsive activity. J. Physiol. 1958, 140, 381-407. [PubMed] 
96. Udenfriend, S.; Weissbach, H.; Bogdanski, D.F. Increase in tissue serotonin following administration of its precursor 5hydroxytryptophan. J. Biol. Chem. 1957, 224, 803-810. [PubMed]

97. Bogdanski, D.F.; Weissbach, H.; Udenfriend, S. Pharmacological studies with the serotonin precursor, 5-hydroxytryptophan. J. Pharmacol. Exp. Ther. 1958, 122, 182-194.

98. Corne, S.J.; Pickering, R.W.; Warner, B.T. A method for assessing the effects of drugs on the central actions of 5-hydroxytryptamine. Br. J. Pharmacol. Chemother. 1963, 20, 106-120. [CrossRef]

99. Martin, P.; Frances, H.; Simon, P. Dissociation of head twitches and tremors during the study of interactions with 5hydroxytryptophan in mice. J. Pharmacol. Methods 1985, 13, 193-200. [CrossRef]

100. Endo, Y. Evidence that the accumulation of 5-hydroxytryptamine in the liver but not in the brain may cause the hypoglycemia induced by 5-hydroxytryptophan. Br. J. Pharmacol. 1985, 85, 591-598. [CrossRef]

101. Endo, Y. Suppression and potentiation of 5-hydroxytryptophan-induced hypoglycemia by alpha-monofluoromethyldopacorrelation with the accumulation of 5-hydroxytryptamine in the liver. Br. J. Pharmacol. 1987, 90, 161-165.

102. Yang, T.H.; Hsu, P.Y.; Meng, M.H.; Su, C.C. Supplement of 5-hydroxytryptophan before induction suppresses inflammation and collagen-induced arthritis. Arthritis Res. Ther. 2015, 17, 364. [CrossRef] [PubMed]

103. Rogóz, Z.; Skuza, G.; Sowińska, H. The effect of the antihistaminic drugs on the central action of 5-hydroxytryptophan in mice. Polish J. Pharm. Pharm. 1981, 33, 459-465.

104. Truscott, T.C. Effects of phenylalanine and 5-hydroxytryptophan on seizure severity in mice. Pharm. Biochem. Behav. 1975, 3, 939-941. [CrossRef]

105. Carter, R.B.; Dykstra, L.A.; Leander, J.D.; Appel, J.B. Role of peripheral mechanisms in the behavioral effects of 5hydroxytryptophan. Pharmacol. Biochem. Behav. 1978, 9, 249-253. [CrossRef]

106. Sharma, A.; Castellani, R.J.; Smith, M.A.; Muresanu, D.F.; Dey, P.K.; Sharma, H.S. 5-hydroxytryptophan: A precursor of serotonin influences regional blood-brain barrier breakdown, cerebral blood flow, brain edema formation, and neuropathology. In New Therapeutic Strategies for Brain Edema and Cell Injury; Sharma, H.S., Sharma, A., Eds.; Academic Press: Cambridge, MA, USA, 2019; pp. 1-44.

107. Yap, C.Y.; Taylor, D.A. Involvement of 5-ht2 receptors in the wet-dog shake behaviour induced by 5-hydroxytryptophan in the rat. Neuropharmacology 1983, 22, 801-804. [CrossRef]

108. Hadzović, S.; Ernst, A.M. The effect of 5-hydroxytryptamine and 5-hydroxytryptophan on extra-pyramidal function. Eur. J. Pharmacol. 1969, 6, 90-95. [CrossRef]

109. Meltzer, H.Y.; Fang, V.S. Effect of apomorphine plus 5-hydroxytryptophan on plasma prolactin levels in male rats. Psychopharmacol. Commun. 1976, 2, 189-198.

110. Ohgo, S.; Kato, Y.; Chihara, K.; Imura, H.; Maeda, K. Effect of hypothalamic surgery on prolactin release induced by 5hydroxytryptophan (5-htp) in rats. Endocrinol. Jpn. 1976, 23, 485-491. [CrossRef]

111. Preziosi, P.; Cerrito, F.; Vacca, M. Effects of naloxone on the secretion of prolactin and corticosterone induced by 5hydroxytryptophan and a serotonergic agonist, mcpp. Life Sci. 1983, 32, 2423-2430. [CrossRef]

112. Hingtgen, J.N.; Fuller, R.W.; Mason, N.R.; Aprison, M.H. Blockade of a 5-hydroxytryptophan-induced animal-model of depression with a potent and selective 5-ht2 receptor antagonist (ly53857). Biol. Psychiatry 1985, 20, 592-597. [CrossRef]

113. Dreshfield-Ahmad, L.J.; Thompson, D.C.; Schaus, J.M.; Wong, D.T. Enhancement in extracelllar serotonin levels by 5hydroxytryptophan loading after administration of way 100635 and fluoxetine. Life Sci. 2000, 66, 2035-2041. [CrossRef]

114. Blundell, J.E.; Latham, C.J. Serotonergic influences on food intake: Effect of 5-hydroxytryptophan on parameters of feeding behaviour in deprived and free-feeding rats. Pharmacol. Biochem. Behav. 1979, 11, 431-437. [CrossRef]

115. Oconnor, L.H.; Feder, H.H. Estradiol and progesterone influence 1-5-hydroxytryptophan-induced myoclonus in male guinea-pigssex-differences in serotonin steroid interactions. Brain Res. 1985, 330, 121-125. [CrossRef]

116. Pappert, E.J.; Goetz, C.G.; Stebbins, G.T.; Belden, M.; Carvey, P.M. 5-hydroxytryptophan-induced myoclonus in guinea pigs: Mediation through 5-ht1/2 receptor subtypes. Eur. J. Pharmacol. 1998, 347, 51-56. [CrossRef]

117. Kojima, S.; Ikeda, M.; Kamikawa, Y. Investigation into the 5-hydroxytryptophan-evoked luminal 5-hydroxytryptamine release from the guinea pig colon. Jpn. J. Pharmacol. 2000, 84, 174-178. [CrossRef] [PubMed]

118. Zuzina, A.B.; Vinarskaya, A.K.; Balaban, P.M. Increase in serotonin precursor levels reinstates the context memory during reconsolidation. Invertebr. Neurosci. 2019, 19, 8. [CrossRef] [PubMed]

119. Banerjee, U.; Burks, T.F.; Feldberg, W.; Goodrich, C.A. Temperature responses and other effects of 5-hydroxytryptophan and 5-hydroxytryptamine when acting from the liquor space in unanaesthetized rabbits. Br. J. Pharmacol. 1970, 38, 688-701. [CrossRef]

120. Fjalland, B. Neuroleptic influence on hyperthermia induced by 5-hydroxytryptophan and p-methoxy-amphetamine in maoipretreated rabbits. Psychopharmacology 1979, 63, 113-117. [CrossRef]

121. Denoyer, M.; Kitahama, K.; Sallanon, M.; Touret, M.; Jouvet, M. 5-hydroxytryptophan uptake and decarboxylating neurons in the cat hypothalamus. Neuroscience 1989, 31, 203-211. [CrossRef]

122. Ellaway, P.H.; Trott, J.R. The mode of action of 5-hydroxytryptophan in facilitating a stretch reflex in the spinal cat. Exp. Brain Res. 1975, 22, 145-162. [CrossRef]

123. Haverback, B.J.; Bogdanski, D.; Hogben, C.A. Inhibition of gastric acid secretion in the dog by the precursor of serotonin, 5-hydroxytryptophan. Gastroenterology 1958, 34, 188-195. [CrossRef] 
124. Schemann, M.; Ehrlein, H.J. 5-hydroxytryptophan and cisapride stimulate propulsive jejunal motility and transit of chyme in dogs. Digestion 1986, 34, 229-235. [CrossRef] [PubMed]

125. Antonaccio, M.J.; Robson, R.D. Centrally-mediated cardiovascular effects of 5-hydroxytryptophan in mao-inhibited dogs: Modification by autonomic antagonists. Arch. Int. Pharmacodyn. Ther. 1975, 213, 200-210. [PubMed]

126. Sugden, D.; Namboodiri, M.A.A.; Klein, D.C.; Grady, R.K.; Mefford, I.N. Ovine pineal indoles-effects of 1-tryptophan or 1-5-hydroxytryptophan administration. J. Neurochem. 1985, 44, 769-772. [CrossRef] [PubMed]

127. Zhao, F.; Ma, C.; Zhao, G.D.; Wang, G.; Li, X.B.; Yang, K.L. Rumen-protected 5-hydroxytryptohan improves sheep melatonin synthesis in the pineal gland and intestinal tract. Med. Sci. Monit. 2019, 25, 3605-3616. [CrossRef] [PubMed]

128. Fletcher, D.J.; Hanson, M.A.; Moore, P.J.; Nijhuis, J.G.; Parkes, M.J. Stimulation of breathing movements by l-5-hydroxytryptophan in fetal sheep during normoxia and hypoxia. J. Physiol. Lond. 1988, 404, 575-589. [CrossRef]

129. Weaver, S.R.; Prichard, A.S.; Maerz, N.L.; Prichard, A.P.; Endres, E.L.; Hernandez-Castellano, L.E.; Akins, M.S.; Bruckmaier, R.M.; Hernandez, L.L. Elevating serotonin pre-partum alters the holstein dairy cow hepatic adaptation to lactation. PLoS ONE 2017, 12, e0184939. [CrossRef]

130. Martin, T.G. Serotonin syndrome. Ann. Emerg. Med. 1996, 28, 520-526. [CrossRef]

131. Francescangeli, J.; Karamchandani, K.; Powell, M.; Bonavia, A. The serotonin syndrome: From molecular mechanisms to clinical practice. Int. J. Mol. Sci. 2019, 20, 2288. [CrossRef]

132. Turner, E.H.; Loftis, J.M.; Blackwell, A.D. Serotonin a la carte: Supplementation with the serotonin precursor 5-hydroxytryptophan. Pharmacol. Ther. 2006, 109, 325-338. [CrossRef]

133. Agren, H.; Reibring, L.; Hartvig, P.; Tedroff, J.; Bjurling, P.; Hornfeldt, K.; Andersson, Y.; Lundqvist, H.; Langstrom, B. Low brain uptake of 1- c-11 5-hydroxytryptophan in major depression-a positron emission tomography study on patients and healthy-volunteers. Acta Psychiatr. Scand. 1991, 83, 449-455. [CrossRef] [PubMed]

134. Ryan, N.D.; Birmaher, B.; Perel, J.M.; Dahl, R.E.; Meyer, V.; Alshabbout, M.; Iyengar, S.; Puigantich, J. Neuroendocrine response to 1-5-hydroxytryptophan challenge in prepubertal major depression-depressed vs normal-children. Arch. Gen. Psychiatry 1992, 49, 843-851. [CrossRef] [PubMed]

135. Coppen, A.; Shaw, D.M.; Malleson, A. Changes in 5-hydroxytryptophan metabolism in depression. Br. J. Psychiatry J. Ment. Sci. 1965, 111, 105-107. [CrossRef] [PubMed]

136. Persson, T.; Roos, B.E. 5-hydroxytryptophan for depression. Lancet 1967, 2, 987-988. [CrossRef]

137. Byerley, W.F.; Judd, L.L.; Reimherr, F.W.; Grosser, B.I. 5-hydroxytryptophan-a review of its antidepressant efficacy and adverseeffects. J. Clin. Psychopharmacol. 1987, 7, 127-137.

138. Zmilacher, K.; Battegay, R.; Gastpar, M. L-5-hydroxytryptophan alone and in combination with a peripheral decarboxylase inhibitor in the treatment of depression. Neuropsychobiology 1988, 20, 28-35. [CrossRef]

139. Smarius, L.; Jacobs, G.E.; Hoeberechts-Lefrandt, D.H.M.; de Kam, M.L.; van der Post, J.P.; de Rijk, R.; van Pelt, J.; Schoemaker, R.C.; Zitman, F.G.; van Gerven, J.M.A.; et al. Pharmacology of rising oral doses of 5-hydroxytryptophan with carbidopa. J. Psychopharmacol. 2008, 22, 426-433. [CrossRef]

140. Van Praag, H.M. In search of the mode of action of antidepressants. 5-htp/tyrosine mixtures in depressions. Neuropharmacology 1983, 22, 433-440. [CrossRef]

141. Meltzer, H.Y.; Umberkoman-Wiita, B.; Robertson, A.; Tricou, B.J.; Lowy, M.; Perline, R. Effect of 5-hydroxytryptophan on serum cortisol levels in major affective disorders. I. Enhanced response in depression and mania. Arch. Gen. Psychiatry 1984, 41, 366-374. [CrossRef]

142. van Praag, H.M.; van den Burg, W.; Bos, E.R.; Dols, L.C. 5-hydroxytryptophan in combination with clomipramine in "therapyresistant" depressions. Psychopharmacologia 1974, 38, 267-269. [CrossRef]

143. Aliño, J.J.; Gutierrez, J.L.; Iglesias, M.L. 5-hydroxytryptophan (5-htp) and a maoi (nialamide) in the treatment of depressions. A double-blind controlled study. Int. Pharm. 1976, 11, 8-15.

144. Mendlewicz, J.; Youdim, M.B. Antidepressant potentiation of 5-hydroxytryptophan by l-deprenil in affective illness. J. Affect Disord. 1980, 2, 137-146. [CrossRef]

145. Kious, B.M.; Sabic, H.; Sung, Y.H.; Kondo, D.G.; Renshaw, P. An open-label pilot study of combined augmentation with creatine monohydrate and 5-hydroxytryptophan for selective serotonin reuptake inhibitor- or serotonin-norepinephrine reuptake inhibitor-resistant depression in adult women. J. Clin. Psychopharmacol. 2017, 37, 578-583. [CrossRef] [PubMed]

146. Kahn, R.S.; Westenberg, H.G.M. L-5-hydroxytryptophan in the treatment of anxiety disorders. J. Affect. Disord. 1985, 8, 197-200. [CrossRef]

147. Kahn, R.S.; Westenberg, H.G.M.; Verhoeven, W.M.A.; Gispendewied, C.C.; Kamerbeek, W.D.J. Effect of a serotonin precursor and uptake inhibitor in anxiety disorders-a double-blind comparison of 5-hydroxytryptophan, clomipramine and placebo. Int. Clin. Psychopharmacol. 1987, 2, 33-45. [CrossRef]

148. Ishida, A.; Takada, G.; Kobayashi, Y.; Toyoshima, I.; Takai, K. Effect of tetrahydrobiopterin and 5-hydroxytryptophan on hereditary progressive dystonia with marked diurnal fluctuation-a suggestion of the serotonergic system involvement. Tohoku J. Exp. Med. 1988, 154, 233-239. [CrossRef]

149. Denboer, J.A.; Westenberg, H.G.M. Behavioral, neuroendocrine, and biochemical effects of 5-hydroxytryptophan administration in panic disorder. Psychiatry Res. 1990, 31, 267-278. [CrossRef] 
150. Schruers, K.; van Diest, R.; Overbeek, T.; Griez, E. Acute 1-5-hydroxytryptophan administration inhibits carbon dioxide-induced panic in panic disorder patients. Psychiatry Res. 2002, 113, 237-243. [CrossRef]

151. Maron, E.; Toru, I.; Vasar, V.; Shlik, J. The effect of 5-hydroxytryptophan on chotecystokinin-4-induced panic attacks in healthy volunteers. J. Psychopharmacol. 2004, 18, 194-199. [CrossRef]

152. Wyatt, R.J.; Zarcone, V.; Engelman, K.; Dement, W.C.; Snyder, F.; Sjoerdsma, A. Effects of 5-hydroxytryptophan on the sleep of normal human subjects. Electroencephalogr. Clin. Neurophysiol. 1971, 30, 505-509. [CrossRef]

153. Guilleminault, C.; Cathala, J.P.; Castaigne, P. Effects of 5-hydroxytryptophan on sleep of a patient with a brain-stem lesion. Electroencephalogr. Clin. Neurophysiol. 1973, 34, 177-184. [CrossRef]

154. Zarcone, V.; Kales, A.; Scharf, M.; Tan, T.L.; Simmons, J.Q.; Dement, W.C. Repeated oral ingestion of 5-hydroxytryptophan The effect on behavior and sleep processes in two schizophrenic children. Arch. Gen. Psychiatry 1973, 28, 843-846. [CrossRef] [PubMed]

155. Petre-Quadens, O.; De Lee, C. 5-hydroxytryptophan and sleep in down's syndrome. J. Neurol. Sci. 1975, 26, 443-453. [CrossRef]

156. Bruni, O.; Ferri, R.; Miano, S.; Verrillo, E. L-5-hydroxytryptophan treatment of sleep terrors in children. Eur. J. Pediatrics 2004, 163, 402-407. [CrossRef]

157. Metz, J.T.; Holcomb, H.H.; Meltzer, H.Y. Effect of 5-hydroxytryptophan on h-reflex recovery curves in normal subjects and patients with affective-disorders. Biol. Psychiatry 1988, 23, 602-611. [CrossRef]

158. Emanuele, E.; Bertona, M.; Minoretti, P.; Geroldi, D. An open-label trial of 1-5-hydroxytryptophan in subjects with romantic stress. Neuroendocrinol. Lett. 2010, 31, 663-666.

159. Titus, F.; Davalos, A.; Alom, J.; Codina, A. 5-hydroxytryptophan versus methysergide in the prophylaxis of migraine-randomized clinical-trial. Eur. Neurol. 1986, 25, 327-329. [CrossRef]

160. Maissen, C.P.; Ludin, H.P. Comparative efficacy of 5-hydroxytryptophan and propranolol in interval treatment of migraine. Schweiz. Med. Wochenschr. 1991, 121, 1585-1590.

161. Nicolodi, M.; Sicuteri, F. L-5-hydroxytryptophan can prevent nociceptive disorders in man. In Tryptophan, Serotonin and Melatonin: Basic Aspects and Applications; Huether, G., Kochen, W., Simat, T.J., Steinhart, H., Eds.; Springer: New York, NY, USA, 1999; pp. 177-182.

162. Ribeiro, C.A.F.; Portuguese Headache, S. L-5-hydroxytryptophan in the prophylaxis of chronic tension-type headache: A doubleblind, randomized, placebo-controlled study. Headache 2000, 40, 451-456. [CrossRef]

163. Trouillas, P.; Brudon, F.; Adeleine, P. Improvement of cerebellar-ataxia with levorotatory form of 5-hydroxytryptophan-a double-blind-study with quantified data-processing. Arch. Neurol. 1988, 45, 1217-1222. [CrossRef]

164. Trouillas, P.; Serratrice, G.; Laplane, D.; Rascol, A.; Augustin, P.; Barroche, G.; Clanet, M.; Degos, C.F.; Desnuelle, C.; Dumas, R.; et al. Levorotatory form of 5-hydroxytryptophan in friedreichs ataxia-results of a double-blind drug-placebo cooperative study. Arch. Neurol. 1995, 52, 456-460. [CrossRef] [PubMed]

165. Rus, A.; Molina, F.; Del Moral, M.L.; Ramirez-Exposito, M.J.; Martinez-Martos, J.M. Catecholamine and indolamine pathway: A case-control study in fibromyalgia. Biol. Res. Nurs. 2018, 20, 577-586. [CrossRef] [PubMed]

166. Maffei, M.E. Fibromyalgia: Recent advances in diagnosis, classification, pharmacotherapy and alternative remedies. Int. J. Mol. Sci. 2020, 21, 7877. [CrossRef] [PubMed]

167. Caruso, I.; Puttini, P.S.; Cazzola, M.; Azzolini, V. Double-blind-study of 5-hydroxytryptophan versus placebo in the treatment of primary fibromyalgia syndrome. J. Int. Med Res. 1990, 18, 201-209. [CrossRef] [PubMed]

168. Volicer, L.; Langlais, P.J.; Matson, W.R.; Mark, K.A.; Gamache, P.H. Serotoninergic system in dementia of the alzheimer typeabnormal forms of 5-hydroxytryptophan and serotonin in cerebrospinal-fluid. Arch. Neurol. 1985, 42, 1158-1161. [CrossRef] [PubMed]

169. Sano, I.; Taniguchi, K. [1-5-hydroxytryptophan(1-5-htp) therapy of parkinson's disease. 2]. Munch. Med. Wochenschr. (1950) 1972, 114, 1717-1719.

170. Chase, T.N. 5-hydroxytryptophan in parkinsonism. Lancet (London, England) 1970, 2, 1029-1030. [CrossRef]

171. Magnussen, I.; Jensen, T.S.; Rand, J.H.; Van Woert, M.H. Plasma accumulation of metabolism of orally administered single dose 1-5-hydroxytryptophan in man. Acta Pharmacol. Toxicol. (Copenh) 1981, 49, 184-189. [CrossRef]

172. Meloni, M.; Puligheddu, M.; Carta, M.; Cannas, A.; Figorilli, M.; Defazio, G. Efficacy and safety of 5-hydroxytryptophan on depression and apathy in parkinson's disease: A preliminary finding. Eur. J. Neurol. 2020, 27, 779-786. [CrossRef]

173. Growdon, J.H.; Young, R.R.; Shahani, B.T. L-5-hydroxytryptophan in treatment of several different syndromes in which myoclonus is prominent. Neurology 1976, 26, 1135-1140. [CrossRef]

174. Magnussen, I.; Dupont, E.; Prange-Hansen, A.; de Fine Olivarius, B. Palatal myoclonus treated with 5-hydroxytryptophan and a decarboxylase-inhibitor. Acta Neurol. Scand. 1977, 55, 251-253. [CrossRef] [PubMed]

175. Gascon, G.; Wallenberg, B.; Daif, A.K.; Ozand, P. Successful treatment of cherry red spot myoclonus syndrome with 5hydroxytryptophan. Ann. Neurol. 1988, 24, 453-455. [CrossRef] [PubMed]

176. Nakano, K.; Hayakawa, T.; Shishikura, K.; Ohsawa, M.; Suzuki, H.; Fukuyama, Y. Improvement of action myoclonus by an administration of 5-hydroxytryptophan and carbidopa in a child with muscular subsarcolemmal hyperactivity. Brain Dev. 1990, 12, 516-520. [CrossRef] 
177. Jimenezjimenez, F.J.; Roldan, A.; Zancada, F.; Molinaarjona, J.A.; Fernandezballesteros, A.; Santos, J. Spinal myoclonus-successful treatment with the combination of sodium valproate and 1-5-hydroxytryptophan. Clin. Neuropharmacol. 1991, 14, 186-190. [CrossRef]

178. Ceci, F.; Cangiano, C.; Cairella, M.; Cascino, A.; Delben, M.; Muscaritoli, M.; Sibilia, L.; Fanelli, F.R. The effects of oral 5hydroxytryptophan administration on feeding-behavior in obese adult female subjects. J. Neural. Transm. 1989, 76, $109-117$. [CrossRef] [PubMed]

179. Cangiano, C.; Ceci, F.; Cascino, A.; Delben, M.; Laviano, A.; Muscaritoli, M.; Antonucci, F.; Rossifanelli, F. Eating behavior and adherence to dietary prescriptions in obese adult subjects treated with 5-hydroxytryptophan. Am. J. Clin. Nutr. 1992, 56, 863-867. [CrossRef] [PubMed]

180. Kato, Y.; Nakai, Y.; Imura, H.; Chihara, K.; Ogo, S. Effect of 5-hydroxytryptophan (5-htp) on plasma prolactin levels in man. J. Clin. Endocrinol. Metab. 1974, 38, 695-697. [CrossRef]

181. Sueldo, C.E.; Duda, M.; Kletzky, O.A. Influence of sequential doses of 5-hydroxytryptophan on prolactin-release. Am. J. Obstet. Gynecol. 1986, 154, 424-427. [CrossRef]

182. Vlasses, P.H.; Rotmensch, H.H.; Swanson, B.N.; Clementi, R.A.; Ferguson, R.K. Effect of repeated doses of 1-5-hydroxytryptophan and carbidopa on prolactin and aldosterone secretion in man. J. Endocrinol. Investig. 1989, 12, 87-91. [CrossRef]

183. Keithahn, C.; Lerchl, A. 5-hydroxytryptophan is a more potent in vitro hydroxyl radical scavenger than melatonin or vitamin c. J. Pineal Res. 2005, 38, 62-66. [CrossRef]

184. Derlacz, R.A.; Sliwinska, M.; Piekutowska, A.; Winiarska, K.; Drozak, J.; Bryla, J. Melatonin is more effective than taurine and 5-hydroxytryptophan against hyperglycemia-induced kidney-cortex tubules injury. J. Pineal Res. 2007, 42, 203-209. [CrossRef] [PubMed]

185. Reyes-Gonzales, M.C.; Fuentes-Broto, L.; Martinez-Ballarin, E.; Miana-Mena, F.J.; Berzosa, C.; Garcia-Gil, F.A.; Aranda, M.; Garcia, J.J. Effects of tryptophan and 5-hydroxytryptophan on the hepatic cell membrane rigidity due to oxidative stress. J. Membr. Biol. 2009, 231, 93-99. [CrossRef] [PubMed]

186. Bae, S.J.; Lee, J.S.; Kim, J.M.; Lee, E.K.; Han, Y.K.; Kim, H.J.; Choi, J.; Ha, Y.M.; No, J.K.; Kim, Y.H.; et al. 5-hydroxytrytophan inhibits tert-butylhydroperoxide (t-bhp)-induced oxidative damage via the suppression of reactive species (rs) and nuclear factor-kappa b (nf-kappa b) activation on human fibroblast. J. Agric. Food Chem. 2010, 58, 6387-6394. [CrossRef] [PubMed]

187. Chae, H.S.; Kang, O.H.; Choi, J.G.; Oh, Y.C.; Lee, Y.S.; Jang, H.J.; Kim, J.H.; Park, H.; Jung, K.Y.; Sohn, D.H.; et al. 5hydroxytryptophan acts on the mitogen-activated protein kinase extracellular-signal regulated protein kinase pathway to modulate cyclooxygenase- 2 and inducible nitric oxide synthase expression in raw 264.7 cells. Biol. Pharm. Bull. 2009, 32, 553-557. [CrossRef] [PubMed]

188. Gwaltney-Brant, S.M.; Albretsen, J.C.; Khan, S.A. 5-hydroxytryptophan toxicosis in dogs: 21 cases (1989-1999). J. Am. Vet. Med Assoc. 2000, 216, 1937-1940. [CrossRef] [PubMed]

189. Shapiro, S. Tryptophan produced by showa denko and epidemic eosinophilia-myalgia syndrome-comment. J. Rheumatol. 1996, 23, 89-91.

190. Kilbourne, E.M.; Philen, R.M.; Kamb, M.L.; Falk, H. Tryptophan produced by showa denko and epidemic eosinophilia-myalgia syndrome. J. Rheumatol. 1996, 23, 81-88.

191. Preuss, H.G.; Echard, B.; Talpur, N.; Funk, K.A.; Bagchi, D. Does 5-hydroxytryptophan cause acute and chronic toxic perturbations in rats? Toxicol. Mech. Methods 2006, 16, 281-286. [CrossRef]

192. Belongia, E.A.; Hedberg, C.W.; Gleich, G.J.; White, K.E.; Mayeno, A.N.; Loegering, D.A.; Dunnette, S.L.; Pirie, P.L.; MacDonald, K.L.; Osterholm, M.T. An investigation of the cause of the eosinophilia-myalgia syndrome associated with tryptophan use. N. Engl. J. Med. 1990, 323, 357-365. [CrossRef]

193. Mayeno, A.N.; Lin, F.; Foote, C.S.; Loegering, D.A.; Ames, M.M.; Hedberg, C.W.; Gleich, G.J. Characterization of peak-e, a novel amino-acid associated with eosinophilia-myalgia-syndrome. Science 1990, 250, 1707-1708. [CrossRef]

194. Goda, Y.; Suzuki, J.; Maitani, T.; Yoshihira, K.; Takeda, M.; Uchiyama, M. 3-anilino-1-alanine, structural determination of uv-5, a contaminant in ems-associated l-tryptophan samples. Chem. Pharm. Bull. 1992, 40, 2236-2238. [CrossRef] [PubMed]

195. Michelson, D.; Page, S.W.; Casey, R.; Trucksess, M.W.; Love, L.A.; Milstien, S.; Wilson, C.; Massaquoi, S.G.; Crofford, L.J.; Hallett, M.; et al. An eosinophilia-myalgia-syndrome related disorder associated with exposure to 1-5-hydroxytryptophan. J. Rheumatol. 1994, 21, 2261-2265. [PubMed] 